\title{
Re-education of the Tumor Microenvironment With Targeted Therapies and Immunotherapies
}

\author{
Shin Foong Ngiow ${ }^{1,2,3 * t}$ and Arabella Young ${ }^{3,4 * t}$ \\ ${ }^{1}$ Department of Systems Pharmacology and Translational Therapeutics, University of Pennsylvania, Philadelphia, PA, \\ United States, ${ }^{2}$ Institute for Immunology, Perelman School of Medicine, University of Pennsylvania, Philadelphia, PA, \\ United States, ${ }^{3}$ Department of Immunology, QIMR Berghofer Medical Research Institute, Herston, QLD, Australia, ${ }^{4}$ Diabetes \\ Center, University of California, San Francisco, San Francisco, CA, United States
}

OPEN ACCESS

Edited by:

Sophie Lucas,

Université Catholique de

Louvain, Belgium

Reviewed by:

Connie Jackaman,

Curtin University, Australia

Robert J. Canter,

University of California, Davis,

United States

*Correspondence:

Shin Foong Ngiow

sngiow@pennmedicine.upenn.edu

Arabella Young

arabella.young@ucsf.edu

tThese authors have contributed equally to this work

Specialty section:

This article was submitted to

Cancer Immunity and Immunotherapy,

a section of the journal

Frontiers in Immunology

Received: 14 April 2020

Accepted: 18 June 2020

Published: 28 July 2020

Citation:

Ngiow SF and Young A (2020)

Re-education of the Tumor Microenvironment With Targeted Therapies and Immunotherapies.

Front. Immunol. 11:1633. doi: 10.3389/fimmu.2020.01633
The clinical success of cancer immunotherapies targeting PD-1 and CTLA-4 has ignited a substantial research effort to improve our understanding of tumor immunity. Recent studies have revealed that the immune contexture of a tumor influences therapeutic response and survival benefit for cancer patients. Identifying treatment modalities that limit immunosuppression, relieve $T$ cell exhaustion, and potentiate effector functions in the tumor microenvironment (TME) is of much interest. In particular, combinatorial therapeutic approaches that re-educate the TME by limiting the accumulation of immunosuppressive immune cells, such as Foxp3 regulatory $T$ cells (Tregs) and tumor-associated macrophages (TAMs), while promoting $\mathrm{CD} 8^{+}$and $\mathrm{CD} 4^{+}$effector $\mathrm{T}$ cell activity is critical. Here, we review key approaches to target these immunosuppressive immune cell subsets and signaling molecules and define the impact of these changes to the tumor milieu. We will highlight the preclinical and clinical evidence for their ability to improve anti-tumor immune responses as well as strategies and challenges for their implementation. Together, this review will provide understanding of therapeutic approaches to efficiently shape the TME and reinvigorate the immune response against cancer.

Keywords: tumor-associated myeloid cells, regulatory $T$ cells (Tregs), natural killer $T$ (NKT) cells, mucosal-associated invariant T (MAIT) cells, adenosine, transforming growth factor (TGF) $\beta$, prostaglandin, immune toxicity

\section{INTRODUCTION}

The clinical validation of key conceptual developments in the field of tumor immunology has engendered much interest in strategies to initiate immune cell function within the tumor microenvironment (TME). Central to effective anti-tumor immunity induced by cancer immunotherapies is the ability to re-educate and re-activate immune effector and cytotoxic $\mathrm{T}$ cells to eliminate cancer cells. As such, immunotherapies targeting $\mathrm{T}$ cell immune checkpoint receptors cytotoxic T-lymphocyte associated protein 4 (CTLA-4) and/or programmed death-1 (PD-1)/programmed death-ligand 1 (PD-L1) have ascended to first-line therapies for a number of solid malignancies (1). Combinatorial anti-tumor efficacy of ipilimumab (anti-CTLA-4) and nivolumab (anti-PD-1) in advanced stage melanoma and renal cell carcinoma (RCC) highlights 
the importance of targeting multiple immune pathways to unleash a more robust anti-tumor immune response $(2,3)$. In addition, FDA-approval of pembrolizumab (anti-PD-1) for the treatment of microsatellite instability-hi (MSI-h) and deficient DNA mismatch repair (dMMR) tumors, the first cancer-site agnostic treatment approval, as well as the correlation between tumor mutational burden and survival outcome sheds light on the significance of tumor genetics in initiating an immune response (4-6). Similarly, PD-L1 status has been shown to impact therapeutic outcome to $\mathrm{PD}-1 / \mathrm{PD}-\mathrm{L} 1$ targeting immunotherapies (7). This highlights that a better understanding of the immune contexture and its interaction with surrounding tumor, stroma, and their derivatives (e.g., chemokines and other soluble factors) is crucial to developing novel therapeutic targets to efficiently shape and re-condition the TME, reinvigorating the immune response against cancer.

Functional anti-tumor immunity relies on both the quality (effector and cytotoxic function) and quantity (numbers and localization) of tumor-infiltrating lymphocytes (TILs) in the TME. Targeting CTLA-4 and PD-1 non-redundantly mobilizes and activates alternate $\mathrm{T}$ cell components, with CTLA- 4 shown to inhibit priming and generation of antigen-specific $\mathrm{T}$ cells in the lymph nodes whereas PD- 1 limits $\mathrm{CD}^{+} \mathrm{T}$ cell numbers in the tissue, for superior anti-tumor outcomes $(8,9)$. The concept of targeting two or more non-redundant immune regulatory pathways for enhanced anti-tumor immunity is not limited to adaptive immunity. A combination of anti-DR5, anti-CD40, and anti-CD137 agonistic antibodies aiming to induce apoptosis in tumor cells, activate antigen presenting cells (innate immunity), and co-stimulate $\mathrm{CD} 8^{+} \mathrm{T}$ cells (adaptive immunity), respectively, has been shown to eradicate both established transplantable and spontaneous tumors (10). Similarly, it has been shown that a combination of recombinant interleukin (IL)-2, antiPD-1, a tumor-antigen targeting antibody, and an additional vaccine targeting three individual tumor antigens is able to eradicate a poorly immunogenic murine melanoma, via the activation of both innate and adaptive immunity (11). Here, we review key approaches to target pathways alternative to mainstream T cell checkpoint receptors to re-educate the TME and alleviate immune suppression and highlight challenges for therapy selection and implementation in the clinic.

\footnotetext{
Abbreviations: A2AR, A2A adenosine receptor; APCs, antigen presenting cells; CSF1, colony stimulating factor 1; CSF1R, colony stimulating factor 1 receptor; COX, cyclooxygenase; CTLA-4, cytotoxic T-lymphocyte associated protein 4; dMMR, deficient DNA mismatch repair; EZH2, enhancer of zeste homolog 2; FLT3L, FMS-like tyrosine kinase 3 ligand; IDO, indoleamine 2,3-dioxygenase; IFN, interferon; irAEs, immune-related adverse events; IL, interleukin; MAIT, mucosal-associated invariant T; MSI-h, microsatellite instability-hi; NKT, natural killer T; NRP1, neuropilin-1; NSCLC, non-small cell lung cancer; PDAC, pancreatic ductal adenocarcinoma; PD-1, programmed death-1; PD-L1, programmed death-ligand 1; PMN-MDSC, polymorphonuclear myeloid-derived suppressor cells; PTSG2, prostaglandin-endoperoxide synthase 2; RCC, renal cell carcinoma; Tregs, regulatory T cells; TAMs, tumor-associated macrophages; TGF, transforming growth factor; TILs, tumor-infiltrating lymphocytes; TME, tumor microenvironment; TNF, tumor necrosis factor; VEGF, vascular endothelial growth factor.
}

\section{IMPROVING TUMOR CONTROL WITH MYELOID CELLS IN THE TME}

Myeloid cells predominate the TME and in many cases evolve to display an immunosuppressive phenotype and ineffective antigen presenting cells (APCs) due to the inflammatory milieu (Figure 1). Tumor-associated macrophages (TAMs) are innate immune cells of heterogeneous origins that have been shown to accumulate in the TME as tumors progress (12-14). The presence of immunosuppressive TAMs can interfere with $\mathrm{T}$ cell-mediated anti-tumor immune responses (15, 16). Given the absence of a universal definition for TAMs, we have listed relevant markers used in individual studies. It has been reported that an accumulation of monocyte-derived TAMs (CD $11 b^{\text {lo }}$ MHC-II $\left.{ }^{-/ l o}\right)$ positively correlates with the proportion of tumorinfiltrating exhausted $\mathrm{PD}-1^{+} \mathrm{CD}^{+} \mathrm{T}$ cells in a mouse model of mammary cancer (12), illustrating a potential mechanism by which TAMs promote tumor escape by modulating the $\mathrm{CD}^{+}$ $\mathrm{T}$ cell response. More recently, it has been shown that TAMs

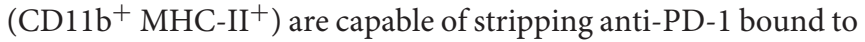
$\mathrm{PD}-1^{+} \mathrm{T}$ cells by binding to the antibody Fc domain, abrogating the anti-tumor activity of this immune checkpoint inhibitor (17). It remains unclear if a similar resistance mechanism also exists in the context of anti-PD-L1 therapy. However, in preclinical mouse models Fc engagement is critical for anti-PDL1 (clone 10F.9G2) therapeutic efficacy by enabling depletion of immunosuppressive TAMs (CD11b $\left.{ }^{+} \mathrm{F} 4 / 80^{+}\right)$(18). Therefore, defining the functionality of an antibodies $\mathrm{Fc}$ region for optimal therapeutic activity in the context of both $\mathrm{T}$ cells and myeloid cells is an important consideration. Additionally, modulating TAMs via targeted depletion, inhibiting active migration, and promoting activation and differentiation, as a means to reeducate the TME may increase permissiveness to immune checkpoint inhibitor therapy.

The colony stimulating factor 1 (CSF1)/CSF1 receptor (CSF1R) axis is crucial for TAM differentiation (19). Selective depletion of TAMs by targeting CSF1R using monoclonal antibodies or small molecule inhibitors has been shown to restrict $\mathrm{CSF}^{+} \mathrm{R}^{+} \mathrm{TAM}$ accumulation in the TME, leading to reduced tumor growth in a number of mouse models (2023). Depletion of $\mathrm{CSF}_{\mathrm{R}}{ }^{+}$TAMs demonstrated efficacy in improving a wide range of existing cancer therapies, including chemotherapy, oncogene-targeted therapy, and immunotherapy $(21,23,24)$. In preclinical BRAF-mutant melanoma, coadministration of PLX3397 (CSF1R inhibitor) together with PLX4720 (mutant BRAF inhibitor) effectively sensitizes a PD-1-resistant tumor model to anti-PD-1/PD-L1 therapies (23). However, CSF1R inhibition induces the expansion of polymorphonuclear myeloid-derived suppressor cells (PMNMDSC) that may abrogate the efficacy of combination CSF1R inhibition and anti-PD-1 treatment $(23,25)$. Evidence that targeting CSF1R and CXCR2 signaling to inhibit TAM and PMNMDSC expansion, respectively, alongside anti-PD-1 facilitates improved anti-tumor immune responses than either doublet combination (25). Alternatively, targeting the CCL2/CCR2 axis, a key chemokine pathway involved in macrophage migration to inflammatory sites, to limit their entry into the TME 


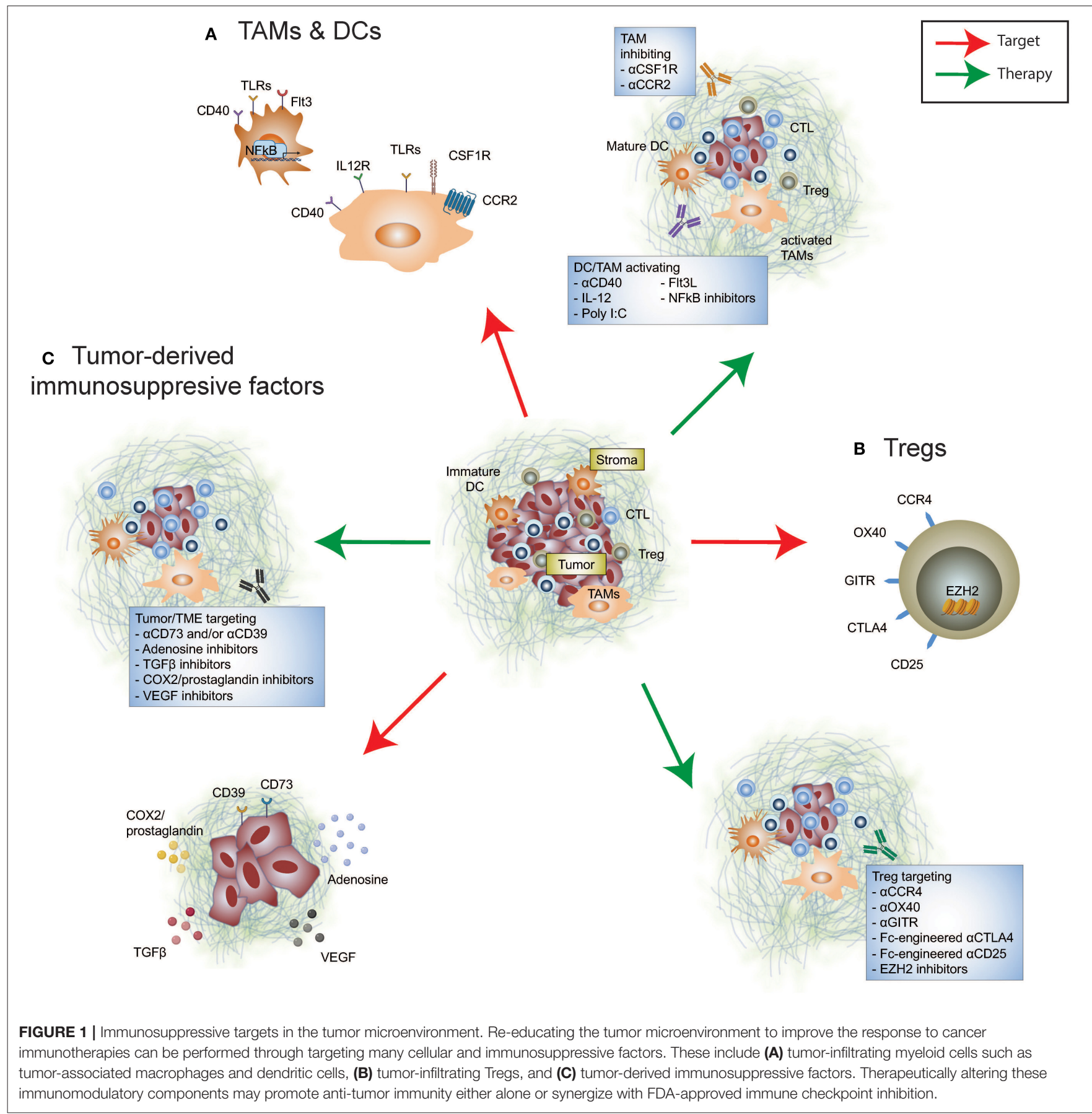

enabled numerical and functional improvement of intratumoral lymphocyte infiltrate (26-29). Wu et al. demonstrated improved survival outcomes in cutaneous T-cell lymphoma-bearing mice treated with a CCR2 inhibitor and anti-PD-1 (28). Collectively, these studies highlight that inhibition of pro-tumor TAMs in the TME reinvigorates the anti-PD-1-driven $\mathrm{T}$ cell response. Of note, a phase I/II clinical trial accessing the combinatorial effect of nivolumab, GVAX (a cancer vaccine expressing GM-CSF) and BMS-813160 (a CCR2/CCR5 dual antagonist) in pancreatic ductal adenocarcinoma (PDAC) is currently underway (NCT03767582).

It is worth highlighting that not all tumor-infiltrating myeloid cells promote tumor growth. The production of CXCL9 and CXCL10, predominantly by TAMs $\left(\mathrm{CD} 11 \mathrm{~b}^{+} \mathrm{Ly}^{\mathrm{int}} \mathrm{CD} 11 \mathrm{c}^{+}\right.$ $\mathrm{F} 4 / 80^{+}$), enhances $\mathrm{CD}^{+} \mathrm{T}$ cell infiltration and tumor control in response to combination anti-PD- 1 and anti-CTLA- 4 in a mouse model of mammary adenocarcinoma (30). High production of these chemokines within the TME is associated with better 
survival outcomes in melanoma patients receiving combination treatment (30). In light of these findings, reprogramming these innate immune cell subsets may be beneficial due to their antigen presenting properties promoting infiltration of an effective anti-tumor $\mathrm{T}$ cell response. In KPC (LSL-Kras ${ }^{\mathrm{G} 12 \mathrm{D} /+}{ }^{+}$;SLTrp53 ${ }^{\mathrm{R} 172 \mathrm{H} /{ }_{+}} ; \mathrm{Pdx}-1$-Cre) PDAC TAMs $\left(\mathrm{CD} 11 \mathrm{~b}^{+} \mathrm{Gr}^{-}{ }^{-} \mathrm{F} 4 / 80^{+}\right)$ enable $\mathrm{T}$ cell exclusion and consequently, resistance to immune checkpoint therapy is likely driven by the absence of effector $\mathrm{T}$ cells that can be modulated $(31,32)$. Independent studies of mouse pancreatic models have demonstrated the remodeling activity of the agonistic CD40 antibody by overcoming $\mathrm{T}$ cell exclusion in the TME, leading to improved therapeutic response to anti-CTLA-4, and/or anti-PD-1 (33-35). Using a T cellrich but anti-PD-1 resistant mammary carcinoma model, we have recently demonstrated that IL- 12 induced by an agonistic CD40 antibody could render terminally exhausted PD- $1^{\text {hi }}$ tumorinfiltrating $\mathrm{CD}^{+} \mathrm{T}$ cells into their $\mathrm{PD}-1^{\mathrm{int}}$ progenitor state (36), leading to improved anti-tumor immunity in response to anti-PD-1 following sensitization by anti-CD40 agonism.

An additional therapeutic approach to re-educate the TME and bolster the efficacy of immune checkpoint therapy is combination treatment with FMS-like tyrosine kinase 3 ligand (FLT3L) and poly I:C treatment, to expand and enhance maturation of anti-tumor $\mathrm{CD}_{103^{+}}$dendritic cells (DCs) resulting in a dramatic increase of intratumoral $\mathrm{T}$ cells (37). Notably, T cell-activating IL- 12 producing $\mathrm{CD}_{103}{ }^{+}$DCs diminish over time (37-41), suggesting that they may facilitate tumor control during tumor initiation. Beavis et al. also reported a role for anti-PD-1/CTLA-4 activated CD $4^{+}$Foxp3 $3^{-}$cells in enhancing IL-12 production by $\mathrm{CD}_{103}{ }^{+}$DCs, which in turn promoted $\mathrm{T}$ cell-mediated anti-tumor immunity in mice (42). The persistence of intratumoral stimulatory DCs $\left(\mathrm{CD} 103^{+}\right.$BDCA$3^{+}$) defined by gene expression profiles corelated with improved overall survival outcomes and was associated with higher TIL measurements in metastatic melanoma (43). Mediating the abundance of intratumoral stimulatory DCs was the presence of tumor-infiltrating natural killer cells and expression of FLT3L, together these components may assist in determining antiPD-1 therapeutic response and identify therapeutic strategies to potentiate efficacy (43). More recently, a cluster of DCs named mregDCs (mature DCs enriched in immunomodulatory molecules) co-expressing immunoregulatory genes ( $C d 274$, $P d c d 1 \lg 2$, and $C d 200)$ and maturation genes $(C d 40, C c r 7$, and Il12b) was found in single cell analysis of mouse and human non-small cell lung cancer (NSCLC) DC infiltrate (44). Of note, neutralizing IL-4 was shown to enhance mregDC IL-12 production, repressing lung adenocarcinoma in mice (44). With advances in high-throughput single-cell analysis to provide finedetail of immune infiltrate in tumors, it is likely to facilitate an expansion of our repertoire of novel targets that will assist to re-educate DCs and other myeloid cells specifically in the TME.

\section{RE-EDUCATING SUPPRESSIVE AND UNCONVENTIONAL T CELLS IN THE TME}

Regulatory $\mathrm{T}$ cells (Tregs) serve as a barrier to limit inflammation, however, their enrichment in the TME of established cancer correlates with poor prognosis and a dampened anti-tumor immune response (Figure 1). Clinical studies have resolved that a higher effector/Treg ratio is associated with favorable outcomes in multiple solid cancers $(45,46)$. In addition to Treg-induced suppression of effector $\mathrm{T}$ cells by manipulating their migration, activation, functionality and/or survival $(47,48)$, Tregs are able to form an immunosuppressive barrier capable of limiting the trafficking of activated antigen-specific $\mathrm{CD}^{+} \mathrm{T}$ cells into the TME (49). Importantly, Foxp3 ${ }^{+}$Tregs promote effector $\mathrm{CD}^{+}$and $\mathrm{CD} 8^{+}$TIL dysfunction, with improved cytokineproducing capacity upon Treg depletion and reinvigorated $\mathrm{T}$ cell responses to immune checkpoint blockade (50-52). However, systemic Treg depletion introduced transiently can still increase susceptibility of mice to autoimmunity (53), indicative that identifying an appropriate target to specifically remove intratumoral Foxp $3^{+}$Tregs will be advantageous for maintaining therapeutic safety.

Intratumoral Foxp $3^{+}$Tregs are highly suppressive, with an activated phenotype marked by the expression of several classes of immune receptors [ENTPD1 (CD39), CTLA-4, OX40, and GITR], and chemokine receptors (CCR4). Studies using preclinical mouse models showed that anti-CTLA-4 (clone 9H10, 9D9, and H11; antagonist), anti-OX40 (clone OX86; agonist) and anti-GITR (clone DTA-1; agonist) exhibited varying levels of intratumoral Treg depleting activity in vivo that was critical to their efficacy (54-59). Anti-CTLA-4 (clone 9D9, mouse IgG2a) and anti-OX40 were shown to specifically deplete intratumoral Tregs but not peripheral Tregs $(56,57)$. Tumor-infiltrating Treg depletion by anti-CTLA-4 enhanced anti-PD- 1 sensitivity to the previously resistant AT3 mouse mammary carcinoma (36). In the clinic, mogamulizumab (an anti-human CCR4 antibody, engineered for ADCC activity) was developed to specifically deplete CCR4 ${ }^{+}$suppressive Tregs found in the TME (60), and is undergoing testing in combination with $\mathrm{T}$ cell checkpoint targets in Phase I/II clinical trials (NCT02301130, NCT02705105, NCT02476123, and NCT02946671). While it remains unclear whether combining anti-CCR4 and anti-PD1 provides favorable survival benefits, an increase in the proportion of $\mathrm{CD}^{+} \mathrm{T}$ cells and a reduction in activated Foxp $3^{\text {hi }}$ Tregs was observed in TILs from patients, along with an acceptable safety profile [(61); NCT02476123]. With advances in antibody engineering, we should expect refinement of antibodies for both existing and novel targets to modulate TME-specific Tregs to enhance anti-tumor immunity $(51,62,63)$. Revisiting targeting CD25-expressing Tregs, Vargas et al. found that by altering the IgG backbone (from rat IgG1 to mouse IgG2a) greater specificity was afforded toward intratumoral Treg depleting activity by an Fc-optimized version of CD25 antibody (64). Anti-CD25-mediated intratumoral Treg depletion synergized with PD-1 blockade therapy in a number of mouse cancer models (64), highlighting the importance of remodeling the Treg dynamics within the TME to enhance checkpoint blockade therapy. Translation of this combination needs to be thoroughly examined, to limit the depletion of alternate $\mathrm{CD} 25$-expressing cell types including effector $\mathrm{T}$ cells and NK cells. 
Given the critical role of Tregs in maintaining immune homeostasis, attenuating intratumoral Treg suppressive function may be a safer approach to remodel the TME while minimizing the risk of systemic autoimmunity. Studies from a series of experimental modeling showed that the disruption of Foxp3, the critical transcription factor to maintain Treg lineage, altered their suppressor function (65-67). This also resulted in the generation of pathogenic effector $\mathrm{T}$ cells $(67,68)$. However, disruption of intratumoural Treg suppressive function has been shown without the loss of its Foxp $3^{+}$Treg identity. Neuropilin-1 (NRP1) appears crucial to maintain intratumoural Treg stability without aberrant loss of Foxp3 identity, and anti-NRP1 displayed therapeutic efficacy in suppressing tumor growth (69). Notably, using a co-transfer model of NRP1-intact and NRP1-deficient Tregs, interferon (IFN)- $\gamma$ produced by NRP1-deficient Tregs is capable of causing fragility to the suppressive capacity of NRP1-intact Tregs, resulting in improved host anti-tumor immunity (70). Similar to the role of NRP1 to maintain Treg stability, the histone H3K27 methyltransferase enhancer of zeste homolog 2 (EZH2) has been recently shown to be critical for the maintenance of activated Foxp3 ${ }^{+}$Tregs (71). EZH2 inhibition destabilizes Foxp3 expression and inhibits tumor growth in vivo $(72,73)$. While targeting these pathways may be able to provide an opportunity to dismantle Treg suppression within the TME, these therapies still lack specificity to this cell type. Understanding the role of these molecules in multiple cell types and disease settings is likely to dictate their applicability for utility in cancer immunity.

Besides Tregs, unconventional $\mathrm{T}$ cells have also received considerable interest in tumor immunology for their immunoregulatory role. In contrast to $\mathrm{CD}^{+}$and $\mathrm{CD} 4^{+} \mathrm{T}$ cells that interact with MHC class I and II molecules, unconventional $\mathrm{T}$ cells such as natural killer T (NKT) cells interact with nonclassical MHC CD1d molecules (74). $\alpha$-GalCer (a glycoplipid molecule derived from a marine sponge extract) is a known ligand for NKT cells, and has been widely used to experimentally modulate NKT cells (75). $\alpha$-GalCer-activated NKT cells are capable of producing high levels of cytokines (including IFN- $\gamma$ and IL-21), anti-tumor effector and cytotoxic molecules (perforin and granzymes), and elicit direct tumor lysing properties (7678 ), which assists to alleviate immunosuppression and enhances DC maturation, leading to improved anti-tumor T cell immunity (79-81). Song et al. demonstrated that NKT cells specifically kill monocytes pulsed with neuroblastoma cell lysate and reduce tumor-infiltrating monocytes in a non-classical MHC-dependent manner (82), highlighting a role for NKT cells in shaping the immune infiltrate in the TME. Studies in mice reported superior anti-tumor activity when $\alpha$-GalCer therapy to drive NKT cell activity was combined with anti-PD-1 $(83,84)$. However, most clinical trials assessing the anti-tumor effect of $\alpha$-GalCer-related compounds have not yet yielded promising outcomes (74). Discoveries of novel NKT cell agonists ( $\beta$-mannosylceramide) and improved $\alpha$-GalCer analogs ( $\alpha$-C-GalCer) (74, 85), as well as greater understanding of tumors where this cell type is prominent may assist in harnessing the potential of NKT cells to improve T cell checkpoint therapy.
Mucosal-associated invariant T (MAIT) cells are another class of unconventional $\mathrm{T}$ cell that have gained much attention, given their relative abundance in humans and their association to a number of inflammatory diseases (74). MAIT cells primarily recognize a number of microbial vitamin $\mathrm{B}$ metabolites (such as riboflavin metabolized to 5-OP-RU) (86-89) presented by the unconventional non-polymorphic MHC I-like molecule, MR1 (90). Additional MR1-independent IL-12/18-induced activation has been reported $(91,92)$. Upon activation, MAIT cells are capable of producing cytokines [(IL-17, IL-2, IFN- $\gamma$, and tumor necrosis factor (TNF)], proliferate and gain cytotoxic function (93-95). In the absence of defined tumor antigens binding to tumor-derived MR1, it is reasonable to speculate that MAIT cells may be regulated by microbial antigens and may be more frequent in tumors with a microbial presence. Circulating levels of MAIT cells were reduced in patients with mucosal-originated cancers (gastric, colon, and lung), but appeared normal in patients with breast, liver, or thyroid cancer (96). In colon cancer patients, MAIT cells were shown to be preferentially enriched in the TME in comparison to unaffected tissue (9699). Poor survival prognosis has been associated to increased levels of tumor-infiltrating MAIT cells in colon cancer patients (98). In contrast, MAIT cells did not show a correlation to patient survival in esophageal adenocarcinoma (100). In concordance with the activation of MAIT cells (TCR-MR1 or IL-12/18 cytokine), they likely elicit direct (MAIT cell to tumor cell) and indirect (MAIT cell to non-MAIT cell or IL-12/18 cytokine competition) effects, regulating host antitumor immunity in a TME-specific manner $(74,101)$. Yan et al. recently reported MR1-deficient mice (which lack MAIT cells) showed improved anti-tumor immunity when assessed using models of experimental lung metastasis, subcutaneous tumor growth, and de novo carcinogenesis (102). In light of these findings, a further assessment of MAIT cells in the cancer setting and their relationship to prognosis and therapeutic outcome should be determined. In addition, given a great interest in microbial modification of the TME (103105) determining whether microbes can be used to initiate metabolic functions that promote anti-tumor immunity is also of interest.

\section{LIMITING IMMUNOSUPPRESSIVE FACTORS IN THE TME}

As well as initiation of immunosuppression by immune cell subsets, the tumor itself produces a range of molecules to enable tumor progression and facilitate immune escape (Figure 1). Many of these are soluble factors that prevent overzealous inflammation during tissue damage and infection, however also mediate tumor immune evasion. Transforming growth factor (TGF) $\beta$ plays an essential role in mediating immune homeostasis, however, in the context of tumor, TGF $\beta$ has been shown to both directly promote tumor progression and initiate a broad range of immune responses. These include enhancing suppressive myeloid cell infiltrate $(106,107)$, disabling NK cell function, 
and promoting transition to group 1 innate lymphoid cells in the TME (108), as well as altering the functionality of effector $\mathrm{T}$ cell populations while promoting Treg immune suppression (109-111). SMAD-3, which acts downstream of TGF $\beta 1$ signaling, directly induces PD-1 expression in adoptively transferred tumor antigen-specific $\mathrm{CD}^{+} \mathrm{T}$ cells isolated from the TME (112). This suggests that $\mathrm{PD}$-1-upregulation that facilitates tumor immune escape may in part be dependent on TGF $\beta$. In addition, TGF $\beta$ is associated with excluding $\mathrm{CD}^{+} \mathrm{T}$ cell entry into the tumor core, which is known to diminish immunotherapy efficacy (113). Correspondingly, TGF $\beta 1$ gene expression is significantly higher in patients that show stable or progressive disease, compared to those with complete or partial responses (113). Targeting TGF $\beta$ and therapies directed toward PD-1/PD-L1 or CTLA-4 amplifies tumor control by enabling a robust $\mathrm{T}$ cell response with improved $\mathrm{CD} 4^{+}$and $\mathrm{CD} 8^{+} \mathrm{T}$ cell activation and $\mathrm{CD} 8^{+} \mathrm{T}$ cell cytokine and cell killing capacity (113-116). By inhibiting TGF $\beta$ in combination with PD-1/PD-L1 blockade, CD8 ${ }^{+} \mathrm{T}$ cells also display enhanced capacity to infiltrate the tumor periphery and core, promoting $\mathrm{T}$ cell inflammation, and resolving $\mathrm{T}$ cell exclusion $(113,117)$. This highlights that targeting TGF $\beta$ may be most effective in tumor types in which TGF $\beta$ signaling mediates immune exclusion from the TME.

Impeding the clinical utility of pan-TGF $\beta$ inhibitors (blocking isoforms TGF $\beta 1,-2$, and-3) is the potential for significant toxicity, particularly pertaining to cardiac function. Development of galunisertib (LY2157299), a TGF $\beta$ RI inhibitor, has shown promise for both its anti-tumor activity and ability to modulate the TME to provide improved anti-tumor control to immunotherapies (118). However, due to toxicity concerns, intermittent administration of galunisertib has been performed in clinical trials [(119) NCT01246986]. Whether intermittent drug exposure provides selective pressure for tumor escape is unclear. As TGF $\beta 1$ appears to be the predominantly enriched in human cancers, targeting this isoform specifically may prove advantageous. Development of TGF $\beta 1$-specific inhibitors that promote synergistic anti-tumor immune responses when combined with anti-PD-1, but lack cardiovascular pathologies have been identified and may lead to greater clinical utility (120). Downstream targets of tumor-derived TGF $\beta$ activation may also be more desirable and in some cases are already being assessed for therapeutic potential alongside immune checkpoint inhibitors and other immunomodulatory compounds in the clinic.

Angiogenesis in the TME is an important component to enable nutrient accessibility and maintain tumor growth, this is driven in part by TGF $\beta$ induction of vascular endothelial growth factor (VEGF). While VEGF inhibitors have been approved for a number of indications in both oncology and vascularrelated diseases, in the cancer setting interest in both antiangiogenic and immunomodulatory properties for this target are increasing. Notably, VEGF-A promotes inhibitory checkpoint expression and transcriptional reprogramming relating to exhaustion in $\mathrm{CD}^{+} \mathrm{T}$ cells $(121,122)$. TOX, the transcription factor that mediates $\mathrm{CD}^{+} \mathrm{T}$ cell exhaustion, was shown to be tightly regulated by VEGF-A (122). In addition, both VEGF-A and TOX expression levels were significantly reduced in MSI-h colon cancer patients compared to patients with microsatellite stability (122). MSI-h patients have better survival outcomes in response to cancer immunotherapies, which is predominantly attributed to higher tumor mutational burden (123, 124), but may also be in part be due to reduced angiogenic factors and relieved $\mathrm{T}$ cell exhaustion. By combining VEGF-targeted therapies and anti-PD-1, improved anti-tumor immune response was achieved $(121,122)$. However, TGF $\beta$ and VEGF are not completely redundant, and co-targeting these molecules together either therapeutically or through tumor-specific genetic ablation provides additional therapeutic benefit to overcome immune tolerance in the TME (125). As clinical cohorts involving combination VEGF/TGF $\beta$ and immune checkpoint blockade treatment mature, determining which patients respond to this therapy, but also which patients are refractory and the mechanism that initiates tumor escape is of importance.

Generation of immunosuppressive adenosine limits antitumor immunity (126). Both CD39, which catabolizes ATP to $\mathrm{AMP}$, and CD73, the enzyme that generates adenosine from ATP, are expressed by and relate to poor prognosis in a number of cancer types (127-130). Regulation of tumor-derived CD73 remains complex with multiple mediators identified, including TGF $\beta$ (131, 132). Additional evidence that CD73 expression is driven by adenosine-sensing through host-A2A adenosine receptor (A2AR) expression (133, 134), TNF (135), and hypoxia within the TME $(136,137)$. In melanoma, CD73 levels have been linked to low MITF expression and highly invasive tumors (135). CD73 expression appears to increase with adaptive resistance in anti-PD-1-treated melanoma patients as well as MART-1 adoptive $\mathrm{T}$ cell therapy (135), suggesting that tumor expression may facilitate therapeutic resistance in response to active antitumor immunity. In melanoma patients with innate therapeutic resistance, CD73 is not present or induced with exposure to antiPD-1 treatment (135), likely due to a lack of inflammatory stimuli in the TME. Therapies targeting the adenosinergic pathway have been shown preclinically to potentiate the response of chemotherapies (127), immune checkpoint inhibitors $(138,139)$, chimeric antigen receptor $\mathrm{T}$ cells (140) and oncogenic BRAF inhibitors (141). This can also be through indirectly targeting the adenosine pathway, with both systemic oxygenation which relieves hypoxia-driven adenosine production, and blockade of an alternate mechanism of adenosine-production by inhibiting CD38, with both shown to potentiate the therapeutic efficacy of immune checkpoint blockade (137, 142, 143). Similarly, targeting upstream CD39 has been shown preclinically to promote therapeutic activity of immune checkpoint inhibitors (144), chemotherapies (145), and even can potentiate CD73 blockade in suboptimal concentrations (146). This highlights the complex regulatory network and the multi-faceted combination strategies involving adenosine-related molecules that may add benefit to patient care.

Targeting adenosine production and signaling have both moved forward to early phase clinical trials with promising results (NCT02403193, NCT02503774, NCT03454451). Notably, citforadenant (an A2AR inhibitor) in combination with atezolizumab (anti-PD-L1) initiated therapeutic response in 
both patients naïve to immunotherapies and those refractory to prior immunotherapy exposure, highlighting the potential for this combination to reinvigorate anti-tumor immunity (147). Analysis of tumor biopsies from renal cell carcinoma (RCC) preceding therapeutic intervention revealed an adenosine signature that may predict patients who will benefit from adenosine-related therapies (147). The adenosine signature was consistent with myeloid inflammation and reduced angiogenesis, both of which have been defined as poor prognostically for atezolizumab and sunitinib (tyrosine kinase inhibitor) treatment. This identifies a patient group for which adenosine may be most applicable, that inadvertently are less responsive to current clinically approved therapies for RCC. In addition, an extended disease control rate in response to citforadenant, with or without atezolizumab, was linked to improved $\mathrm{CD}^{+}$ $\mathrm{T}$ cell infiltration (147). Adenosine has previously been shown to limit the proliferation and maturation of lymphocytic immune cell subsets $(126,134)$, and increased immune infiltrate in to the tumor core has been observed in response to co-targeting CD73 and A2AR in preclinical models (133). Understanding the regulation of the adenosinergic pathway in particular tumor types and in response to cancer therapies, including immunotherapy, may identify patient populations where adenosine-related therapies may be implemented with greatest success.

With increasing examination of the TME it is clear that a number of therapeutic regimens may be successfully repurposed in the treatment of cancer. For instance, targeting adenosine has been utilized previously in the setting of neurodegeneration, but has increasingly shown merit for initiating anti-tumor immunity. Additionally, aspirin may provide a combinatorial approach to overcome therapeutic resistance to immune checkpoint inhibitors. Increasing evidence demonstrates that cyclooxygenase (COX)-driven production of prostaglandins mediates anti-PD-1 resistance and limits the proinflammatory tumor milieu (148). COX enzymatic activity is disrupted by high-dose aspirin, which valuably may be repurposed to the cancer setting alongside immunotherapies to promote anti-tumor immunity. Regular aspirin users with colorectal cancer patients displaying low tumor PD-L1 expression are also afforded significantly improved survival outcomes (149). This survival advantage was not identified in PD-L1 high tumors, suggesting that engagement of the PD-1/PD-L1 axis in the TME may abrogate aspirin-mediated anti-tumor benefit and the potential utility of combination treatment. Genetic ablation of prostaglandinendoperoxide synthase 2 (PTSG2), which encodes COX-2, has been shown to promote $\mathrm{CD} 8^{+} \mathrm{T}$ cells and decrease the frequency of Tregs within the TME (150), both of which are predictive markers of good prognosis. Induction of COX-2 may be in part regulated by TGF $\beta$, highlighting the complex nature of direct and indirect regulatory pathways that the tumor elicits to subdue the anti-tumor immune response. Clinical trials to develop an understanding of prostaglandin/COX-2 inhibition and immune checkpoint blockade therapeutic responses are underway in multiple tumor types [(151) NCT03396952, NCT03638297, NCT03864575, NCT03926338].

\section{IMPLEMENTING COMBINATION THERAPEUTIC REGIMENS}

While preclinical studies have identified a number of clinically relevant therapeutic strategies to reinvigorate the immune response against cancer, their successful clinical utility has been difficult to implement (Figure 2). Combining indoleamine 2,3dioxygenase (IDO) inhibition, an enzyme upregulated in human cancers that initiates the breakdown of tryptophan leading to multi-faceted immunosuppression within the TME (152), alongside immune checkpoint inhibitors showed promise for enhancing anti-tumor immunity in mice $(153,154)$. However, in a phase 3 clinical trial assessing the survival benefit for stage III/IV unresectable melanoma patients treated with epacadostat (selective IDO1 inhibitor) and pembrolizumab (antiPD-1), this combination failed to provide additive therapeutic potential compared to pembrolizumab alone (155). Improved understanding of the TME is necessary to assist rational selection of immunotherapies required for optimal treatment outcomes. Of course, this remains a challenge even for clinically approved agents, where aside from tumor PD-L1 expression and genetic stablility of the tumor, no biomarkers for efficacy or toxicity of immune checkpoint inhibitors are approved for clinical use. Significant investment to establish biomarkers to denote responders and non-responders should be performed in early phase clinical trials to identify subgroups for which combination therapies may show greatest activity, an important first-step to facilitate response, mitigate toxicity, and minimize unnecessary cost.

In the same vein, examining optimal timing for immunotherapeutic combinations is often not well-defined. In most cases, therapeutic benefit for novel clinical agents are tested either alone or alongside concurrent anti-PD-1/PD-L1 treatment, often in cancer patients refractory to previous immune checkpoint inhibitor exposure. Preclinical evidence suggests synchronous administration of multiple immunotherapies can in some circumstances be detrimental. Two independent studies identified that concurrent administration of anti-OX40 to antiPD-1 therapy either with or without a tumor vaccine diminished the anti-tumor immune response compared to addition of antiOX40 alone in preclinical mouse models $(156,157)$. Notably, staggering the timing of these therapies where anti-OX40 preceded anti-PD-1 treatment facilitated greatest tumor control (156). Using a preclinical PDAC model, the use of gemcitabine and nab-paclitaxel, a standard chemotherapy combination for PDAC, impaired the efficacy of anti-CD40, anti-PD-1, and anti-CTLA-4 (34). Additionally, transient treatments preceding immune checkpoint inhibition can also significantly re-educate the immune response to promote anti-tumor immunity. In an anti-PD-1-resistant mouse model, a single-dose of agonistic antiCD40 sensitized the TME to anti-PD-1 treatment in a synergistic manner (36). Strongly activating or agonistic therapies may provide greatest benefit as sensitizing agents to remodel the TME and promote entry of anti-tumor immune cells that are then targetable by immune checkpoint blockade. Alternating timing of treatments or reducing the therapeutic window for 


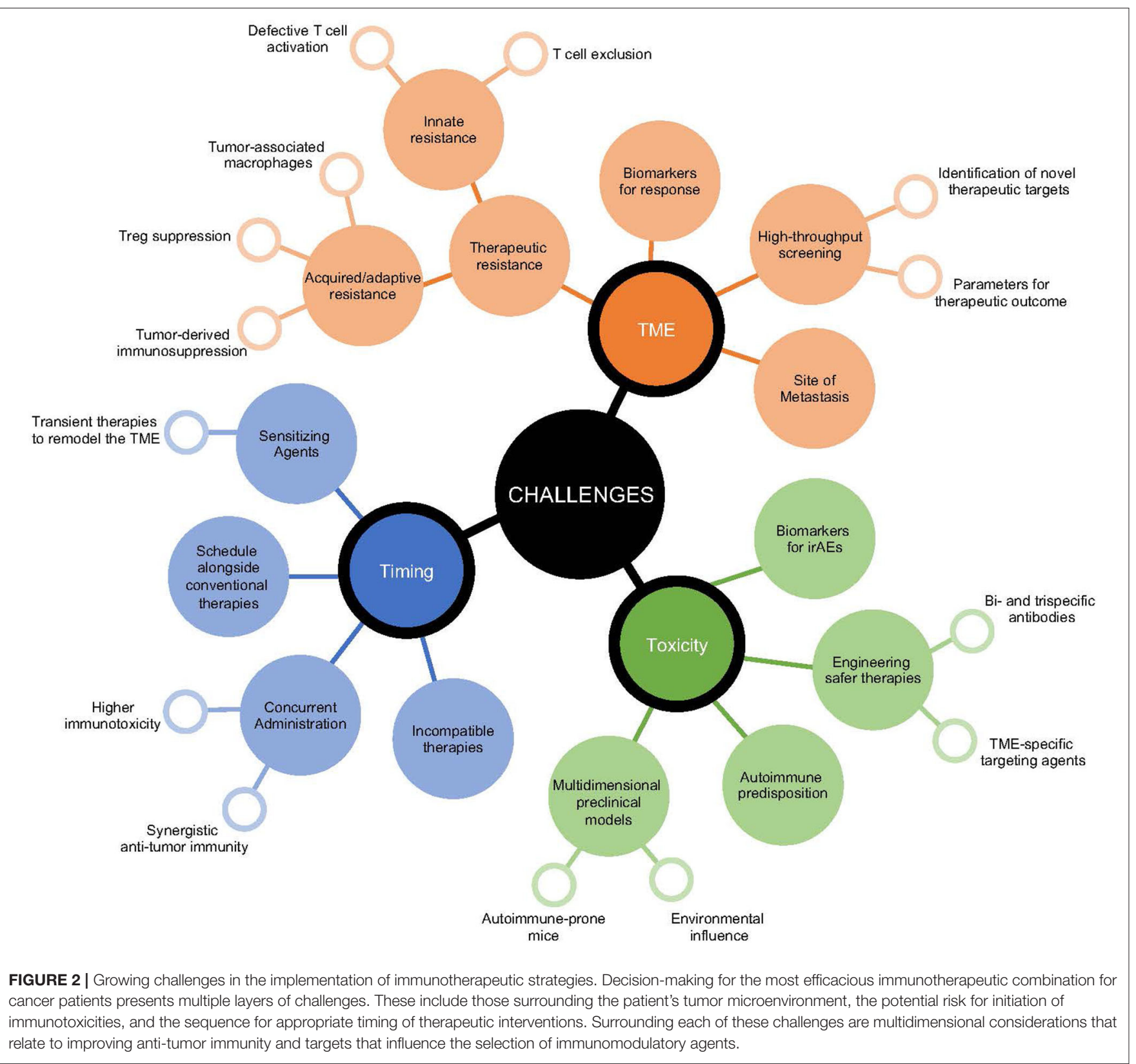

largely inflammatory combinations may also assist to potentiate therapeutic response and minimize immunotherapy-induced immune-related adverse events (irAEs).

\section{CHALLENGES FOR RE-EDUCATING THE TME}

With the advent of high-throughput screening to delineate critical components that prevent immune infiltrate or disable active anti-tumor immunity, a growing understanding of rational targets to re-ignite a therapeutic response is becoming increasingly available (158-161). This aims to equip patients who develop adaptive or acquired resistance with greater tools to re-engage the immune response against cancer and for patients with innate resistance to enable visibility of tumors $(162,163)$. New subgroups of cancer patients that present distinct challenges to the efficacy of immunotherapies are emerging. Of growing interest, is the relationship between metastatic site and therapeutic outcome, in which liver metastasis appears to be a major obstacle even for combination anti-PD-1 and antiCTLA-4 treatment $(164,165)$. Most prominently, melanoma patients bearing liver metastasis have reduced CTLA-4 and PD-1 co-expression in $\mathrm{CD}^{+} \mathrm{T}$ cells (164), which has been shown to stratify therapeutic response to immune checkpoint inhibitor treatment (166). Efforts to provide mechanistic insight 
as to whether therapeutic resistance is due to myeloid cell dysfunction, Treg suppression, and immunosuppressive factors accumulating in the TME are essential, highlighting the need for tailored immunotherapies.

As the number and type of combination immunotherapies expands, the risk for increasing irAEs may also become more prevalent. Combination nivolumab (anti-PD-1) and ipilimumab (anti-CTLA-4) clearly exhibits greater levels of severe grade 3-4 immunotoxicities than either therapy alone $(3,167)$. Surprising levels of irAEs have been observed with other rational combinations. For instance, targeted therapies (such as BRAF inhibitors and MEK inhibitors) have been shown to potentiate immune checkpoint inhibitor activity in preclinical models (168), but when used together in melanoma patients severe irAEs were observed forcing closure of the study $(169,170)$. This highlights a need for improved preclinical models that emulate clinical conditions and allow for simultaneous assessment of tumor control and development of irAEs (171). Developing tumor models in autoimmune-prone mice or lowering the threshold for self-tolerance in mice with available syngeneic tumors that are resistant to autoimmune responses may facilitate improved therapeutic modeling $(53,171,172)$. With the expanding use of cancer immunotherapies in more diverse populations of cancer patients, including those with pre-existing autoimmune diseases or previous immunotherapy-induced irAEs (173), or under persistent immunosuppression due to chronic viral infections (174) and allogeneic transplantation (175), developing preclinical models that incorporate multiple elements relating to tumor origin, patient history, and environment that assist in providing a more informed understanding of the clinical impact of therapeutic combinations will be essential.

As the number of immunotherapeutic targets expands, initiating smarter multi-modal strategies, to provide greater efficacy with lower toxicity will be appealing. Advancement in engineering therapies to have delayed release or greater tissue and cellular specificity have great promise. As mentioned, depletion of intratumoral Tregs without impacting peripheral Tregs would be advantageous for inducing TME-specific modulation of the $\mathrm{CD}^{+}$to Treg ratio, while avoiding toxicity induced by systemic depletion. Notably, the development of a dual variable domain anti-CTLA-4 antibody, which exhibits an outer tumor antigenbinding site that hides the CTLA-4 binding region of the antibody until reaching the TME has been shown to reduce immunotherapy-induced toxicity without impeding anti-tumor immunity (176). Similarly, bispecific or trispecific antibodies that target multiple markers upregulated in the TME on both immune cell subsets and the tumor may also lead to greater efficacy (177, 178). One such example, is the bispecific antibody combination

\section{REFERENCES}

1. Khalil DN, Smith EL, Brentjens RJ, Wolchok JD. The future of cancer treatment: immunomodulation, CARs and combination immunotherapy. Nat Rev Clin Oncol. (2016) 13:394. doi: 10.1038/nrclinonc.2016.65

2. Hammers HJ, Plimack ER, Infante JR, Rini BI, McDermott DF, Lewis LD, et al. Safety and efficacy of nivolumab in combination with ipilimumab in targeting OX40 and CTLA-4, which significantly enhanced $\mathrm{CD}^{+} \mathrm{T}$ cells and reduced Tregs specifically within the TME, leading to better tumor control than either therapy alone (178). In addition to modifying the target antigen, antibodies may also be conjugated to biomaterials or nanoparticles, to ensure sustained, local release (179). Refinement made to antibodies by factoring TME properties, such as $\mathrm{pH}$ activation and $\mathrm{PD}-1$ glycosylation (180-182), should also significantly improve the specificity and potency of immunotherapies and limit unwanted toxicity.

\section{FUTURE DIRECTIONS}

While determining the optimal immunotherapy for an individual TME remains a challenge, encouraging is the range of available strategies to re-educate the immune response against tumor. Refinement of therapeutic targets against cellular and immunomodulatory molecules within the TME are increasing, and their promise for clinical utility is growing. Importantly, greater effort in defining the therapeutic setting where each may be applicable will be essential for clinical success. Since anti-PD-1/PD-L1 has shown value in multiple modalities, examining tumor types where anti-PD-1 activity is limited may yield greatest therapeutic breakthroughs in identifying strategies to remodel inert immune circumstances in the tumor. In deciding on the use of these therapies, a costbenefit analysis relating to the purported immunotoxicity and likelihood for the immunotherapy strategy to enhance antitumor immunity is necessary. This emphasizes a need for rational and selective combination immunotherapies to be utilized within a defined TME in order to re-educate the anti-tumor immune response.

\section{AUTHOR CONTRIBUTIONS}

SN and AY contributed equally to the writing and revision of the manuscript. All authors contributed to the article and approved the submitted version.

\section{FUNDING}

SN was supported by an NHMRC C.J. Martin Fellowship (GNT1111469) and the Mark Foundation for Cancer Research Momentum Fellowhsip. AY was supported by a NHMRC C.J. Martin Fellowship (GNT1143981). Research reported in this publication was supported by the National Cancer Institute of the National Institutes of Health under Award Number K99CA246061 (AY). The content is solely the responsibility of the authors and does not necessarily represent the official views of the National Institutes of Health.

metastatic renal cell carcinoma: the checkmate 016 study. J Clin Oncol. (2017) 35:3851-8. doi: 10.1200/JCO.2016.72.1985

3. Wolchok JD, Chiarion-Sileni V, Gonzalez R, Rutkowski P, Grob JJ, Cowey CL, et al. Overall survival with combined nivolumab and ipilimumab in advanced melanoma. NEngl J Med. (2017) 377:1345-56. doi: 10.1056/NEJMoa1709684

4. Rizvi NA, Hellmann MD, Snyder A, Kvistborg P, Makarov V, Havel JJ, et al. Cancer immunology. mutational landscape determines sensitivity to 
PD-1 blockade in non-small cell lung cancer. Science. (2015) 348:1248. doi: 10.1126/science.aaa1348

5. Goodman AM, Kato S, Bazhenova L, Patel SP, Frampton GM, Miller V, et al. Tumor mutational burden as an independent predictor of response to immunotherapy in diverse cancers. Mol Cancer Ther. (2017) 16:2598608. doi: 10.1158/1535-7163.MCT-17-0386

6. Yarchoan M, Hopkins A, Jaffee EM. Tumor mutational burden and response rate to PD-1 inhibition. N Engl J Med. (2017) 377:25001. doi: 10.1056/NEJMc1713444

7. Teng MW, Ngiow SF, Ribas A, Smyth MJ. Classifying cancers based on T-cell infiltration and PD-L1. Cancer Res. (2015) 75:2139-45. doi: 10.1158/0008-5472.CAN-15-0255

8. Twyman-Saint Victor C, Rech AJ, Maity A, Rengan R, Pauken KE, Stelekati E, et al. Radiation and dual checkpoint blockade activate non-redundant immune mechanisms in cancer. Nature. (2015) 520:3737. doi: $10.1038 /$ nature 14292

9. Wei SC, Levine JH, Cogdill AP, Zhao Y, Anang NAS, Andrews MC, et al. Distinct cellular mechanisms underlie anti-CTLA4 and anti-PD-1 checkpoint blockade. Cell. (2017) 170:1120-33 e17. doi: 10.1016/j.cell.2017.07.024

10. Uno T, Takeda K, Kojima Y, Yoshizawa H, Akiba H, Mittler RS, et al. Eradication of established tumors in mice by a combination antibody-based therapy. Nat Med. (2006) 12:693-8. doi: 10.1038/nm1405

11. Moynihan KD, Opel CF, Szeto GL, Tzeng A, Zhu EF, Engreitz JM, et al. Eradication of large established tumors in mice by combination immunotherapy that engages innate and adaptive immune responses. Nat Med. (2016) 22:1402-10. doi: 10.1038/nm.4200

12. Franklin RA, Liao W, Sarkar A, Kim MV, Bivona MR, Liu K, et al. The cellular and molecular origin of tumor-associated macrophages. Science. (2014) 344:921-5. doi: 10.1126/science.1252510

13. Zhu Y, Herndon JM, Sojka DK, Kim KW, Knolhoff BL, Zuo C, et al. Tissue-resident macrophages in pancreatic ductal adenocarcinoma originate from embryonic hematopoiesis and promote tumor progression. Immunity. (2017) 47:323-38.e6. doi: 10.1016/j.immuni.2017.07.014

14. Gubin MM, Esaulova E, Ward JP, Malkova ON, Runci D, Wong P, et al. High-dimensional analysis delineates myeloid and lymphoid compartment remodeling during successful immune-checkpoint cancer therapy. Cell. (2018) 175:1014-30.e19. doi: 10.1016/j.cell.2018.09.030

15. DeNardo DG, Andreu P, Coussens LM. Interactions between lymphocytes and myeloid cells regulate pro- versus anti-tumor immunity. Cancer Metastasis Rev. (2010) 29:309-16. doi: 10.1007/s10555-010-9223-6

16. Veglia F, Perego M, Gabrilovich D. Myeloid-derived suppressor cells coming of age. Nat Immunol. (2018) 19:108-19. doi: 10.1038/s41590-017-0022-x

17. Arlauckas SP, Garris CS, Kohler RH, Kitaoka M, Cuccarese MF, Yang $\mathrm{KS}$, et al. In vivo imaging reveals a tumor-associated macrophagemediated resistance pathway in anti-PD-1 therapy. Sci Transl Med. (2017) 9:eaal3604. doi: 10.1126/scitranslmed.aal3604

18. Dahan R, Sega E, Engelhardt J, Selby M, Korman AJ, Ravetch JV. FcgammaRs modulate the anti-tumor activity of antibodies targeting the PD-1/PD-L1 axis. Cancer Cell. (2015) 28:285-95. doi: 10.1016/j.ccell.2015.08.004

19. Wynn TA, Chawla A, Pollard JW. Macrophage biology in development, homeostasis and disease. Nature. (2013) 496:44555. doi: 10.1038 /nature 12034

20. Strachan DC, Ruffell B, Oei Y, Bissell MJ, Coussens LM, Pryer N, et al. CSF1R inhibition delays cervical and mammary tumor growth in murine models by attenuating the turnover of tumor-associated macrophages and enhancing infiltration by $\mathrm{CD} 8(+) \mathrm{T}$ cells. Oncoimmunology. (2013) 2:e26968. doi: 10.4161/onci.26968

21. Zhu Y, Knolhoff BL, Meyer MA, Nywening TM, West BL, Luo J, et al. CSF1/CSF1R blockade reprograms tumor-infiltrating macrophages and improves response to T-cell checkpoint immunotherapy in pancreatic cancer models. Cancer Res. (2014) 74:5057-69. doi: 10.1158/0008-5472.CAN-13-3723

22. Mok S, Koya RC, Tsui C, Xu J, Robert L, Wu L, et al. Inhibition of CSF-1 receptor improves the antitumor efficacy of adoptive cell transfer immunotherapy. Cancer Res. (2014) 74:153-61. doi: 10.1158/0008-5472.CAN-13-1816
23. Ngiow SF, Meeth KM, Stannard K, Barkauskas DS, Bollag G, Bosenberg $\mathrm{M}$, et al. Co-inhibition of colony stimulating factor-1 receptor and BRAF oncogene in mouse models of BRAF(V600E) melanoma. Oncoimmunology. (2016) 5:e1089381. doi: 10.1080/2162402X.2015.1089381

24. DeNardo DG, Brennan DJ, Rexhepaj E, Ruffell B, Shiao SL, Madden $\mathrm{SF}$, et al. Leukocyte complexity predicts breast cancer survival and functionally regulates response to chemotherapy. Cancer Discov. (2011) 1:54-67. doi: 10.1158/2159-8274.CD-10-0028

25. Kumar V, Donthireddy L, Marvel D, Condamine T, Wang F, Lavilla-Alonso S, et al. Cancer-associated fibroblasts neutralize the anti-tumor effect of CSF1 receptor blockade by inducing PMN-MDSC infiltration of tumors. Cancer Cell. (2017) 32:654-68.e5. doi: 10.1016/j.ccell.2017.10.005

26. Teng KY, Han J, Zhang X, Hsu SH, He S, Wani NA, et al. Blocking the CCL2-CCR2 axis using CCL2-neutralizing antibody is an effective therapy for hepatocellular cancer in a mouse model. Mol Cancer Ther. (2017) 16:31222. doi: 10.1158/1535-7163.MCT-16-0124

27. Mitchem JB, Brennan DJ, Knolhoff BL, Belt BA, Zhu Y, Sanford DE, et al. Targeting tumor-infiltrating macrophages decreases tumor-initiating cells, relieves immunosuppression, and improves chemotherapeutic responses. Cancer Res. (2013) 73:1128-41. doi: 10.1158/0008-5472.CAN-12-2731

28. Wu X, Singh R, Hsu DK, Zhou Y, Yu S, Han D, et al. A small molecule CCR2 antagonist depletes tumor macrophages and synergizes with anti-PD-1 in a murine model of cutaneous T-cell lymphoma (CTCL). J Invest Dermatol. (2020) 140:1390-400.e4. doi: 10.1016/j.jid.2019.11.018

29. Grossman JG, Nywening TM, Belt BA, Panni RZ, Krasnick BA, DeNardo DG, et al. Recruitment of CCR2(+) tumor associated macrophage to sites of liver metastasis confers a poor prognosis in human colorectal cancer. Oncoimmunology. (2018) 7:e1470729. doi: 10.1080/2162402X.2018.1470729

30. House IG, Savas P, Lai J, Chen AXY, Oliver AJ, Teo ZL, et al. Macrophagederived CXCL9 and CXCL10 are required for antitumor immune responses following immune checkpoint blockade. Clin Cancer Res. (2020) 26:487504. doi: 10.1158/1078-0432.CCR-19-1868

31. Clark CE, Hingorani SR, Mick R, Combs C, Tuveson DA, Vonderheide RH. Dynamics of the immune reaction to pancreatic cancer from inception to invasion. Cancer Res. (2007) 67:9518-27. doi: 10.1158/0008-5472.CAN-07-0175

32. Aiello NM, Bajor DL, Norgard RJ, Sahmoud A, Bhagwat N, Pham $\mathrm{MN}$, et al. Metastatic progression is associated with dynamic changes in the local microenvironment. Nat Commun. (2016) 7:12819. doi: $10.1038 /$ ncomms 12819

33. Vonderheide RH. The immune revolution: a case for priming, not checkpoint. Cancer Cell. (2018) 33:563-9. doi: 10.1016/j.ccell.2018.03.008

34. Morrison AH, Diamond MS, Hay CA, Byrne KT, Vonderheide RH. Sufficiency of CD40 activation and immune checkpoint blockade for T cell priming and tumor immunity. Proc Natl Acad Sci USA. (2020) 117:802231. doi: 10.1073/pnas.1918971117

35. Luheshi NM, Coates-Ulrichsen J, Harper J, Mullins S, Sulikowski MG, Martin P, et al. Transformation of the tumour microenvironment by a CD40 agonist antibody correlates with improved responses to PD-L1 blockade in a mouse orthotopic pancreatic tumour model. Oncotarget. (2016) 7:1850820. doi: $10.18632 /$ oncotarget.7610

36. Ngiow SF, Young A, Blake SJ, Hill GR, Yagita H, Teng MW, et al. Agonistic CD40 mAb-driven IL12 reverses resistance to anti-PD1 in a T-cell-rich tumor. Cancer Res. (2016) 76:626677. doi: 10.1158/0008-5472.CAN-16-2141

37. Salmon H, Idoyaga J, Rahman A, Leboeuf M, Remark R, Jordan S, et al. Expansion and activation of $\mathrm{CD} 103(+)$ dendritic cell progenitors at the tumor site enhances tumor responses to therapeutic PD-L1 and BRAF inhibition. Immunity. (2016) 44:924-38. doi: 10.1016/j.immuni.2016.03.012

38. Hildner $K$, Edelson BT, Purtha WE, Diamond $M$, Matsushita $H$, Kohyama M, et al. Batf3 deficiency reveals a critical role for CD8alpha+ dendritic cells in cytotoxic T cell immunity. Science. (2008) 322:1097100. doi: $10.1126 /$ science. 1164206

39. Broz ML, Binnewies M, Boldajipour B, Nelson AE, Pollack JL, Erle DJ, et al. Dissecting the tumor myeloid compartment reveals rare activating antigen-presenting cells critical for T cell immunity. Cancer Cell. (2014) 26:638-52. doi: 10.1016/j.ccell.2014.09.007 
40. Ruffell B, Chang-Strachan D, Chan V, Rosenbusch A, Ho CM, Pryer $\mathrm{N}$, et al. Macrophage IL-10 blocks CD8 $+\mathrm{T}$ cell-dependent responses to chemotherapy by suppressing IL-12 expression in intratumoral dendritic cells. Cancer Cell. (2014) 26:623-37. doi: 10.1016/j.ccell.2014.09.006

41. Roberts EW, Broz ML, Binnewies M, Headley MB, Nelson AE, Wolf DM, et al. Critical role for CD103(+)/CD141(+) dendritic cells bearing CCR7 for tumor antigen trafficking and priming of $\mathrm{T}$ cell immunity in melanoma. Cancer Cell. (2016) 30:324-36. doi: 10.1016/j.ccell.2016.06.003

42. Beavis PA, Henderson MA, Giuffrida L, Davenport AJ, Petley EV, House IG, et al. Dual PD-1 and CTLA-4 checkpoint blockade promotes antitumor immune responses through CD4(+)Foxp3(-) cell-mediated modulation of CD103(+) dendritic cells. Cancer Immunol Res. (2018) 6:106981. doi: 10.1158/2326-6066.CIR-18-0291

43. Barry KC, Hsu J, Broz ML, Cueto FJ, Binnewies M, Combes AJ, et al. A natural killer-dendritic cell axis defines checkpoint therapy-responsive tumor microenvironments. Nat Med. (2018) 24:1178-91. doi: 10.1038/s41591-018-0085-8

44. Maier B, Chen ST, Tung N, Chang C, LeBerichel J, Chudnovskiy A, et al. A conserved dendritic-cell regulatory program limits antitumour immunity. Nature. (2020) 508:257-62. doi: 10.1038/s41586-020-2134-y

45. Fridman WH, Pages F, Sautes-Fridman C, Galon J. The immune contexture in human tumours: impact on clinical outcome. Nat Rev Cancer. (2012) 12:298-306. doi: 10.1038/nrc3245

46. Shang B, Liu Y, Jiang SJ, Liu Y. Prognostic value of tumor-infiltrating FoxP3+ regulatory T cells in cancers: a systematic review and meta-analysis. Sci Rep. (2015) 5:15179. doi: 10.1038/srep15179

47. Tanaka A, Sakaguchi S. Regulatory T cells in cancer immunotherapy. Cell Res. (2017) 27:109-18. doi: 10.1038/cr.2016.151

48. Binnewies M, Mujal AM, Pollack JL, Combes AJ, Hardison EA, Barry KC, et al. Unleashing type-2 dendritic cells to drive protective antitumor CD4(+) T cell immunity. Cell. (2019) 177:556-71e16. doi: 10.1016/j.cell.2019.02.005

49. Qi S, Li H, Lu L, Qi Z, Liu L, Chen L, et al. Long-term intravital imaging of the multicolor-coded tumor microenvironment during combination immunotherapy. Elife. (2016) 5:e14756. doi: 10.7554/eLife.14756

50. Taylor NA, Vick SC, Iglesia MD, Brickey WJ, Midkiff BR, McKinnon KP, et al. Treg depletion potentiates checkpoint inhibition in claudin-low breast cancer. J Clin Invest. (2017) 127:3472-83. doi: 10.1172/JCI90499

51. Sakuishi K, Ngiow SF, Sullivan JM, Teng MW, Kuchroo VK, Smyth $\mathrm{MJ}$, et al. TIM3(+)FOXP3(+) regulatory $\mathrm{T}$ cells are tissue-specific promoters of T-cell dysfunction in cancer. Oncoimmunology. (2013) 2:e23849. doi: 10.4161/onci.23849

52. Penaloza-MacMaster P, Kamphorst AO, Wieland A, Araki K, Iyer SS, West $\mathrm{EE}$, et al. Interplay between regulatory $\mathrm{T}$ cells and PD-1 in modulating $\mathrm{T}$ cell exhaustion and viral control during chronic LCMV infection. J Exp Med. (2014) 211:1905-18. doi: 10.1084/jem.20132577

53. Liu J, Blake SJ, Harjunpaa H, Fairfax KA, Yong MC, Allen S, et al. Assessing immune-related adverse events of efficacious combination immunotherapies in preclinical models of cancer. Cancer Res. (2016) 76:5288-301. doi: 10.1158/0008-5472.CAN-16-0194

54. Coe D, Begom S, Addey C, White M, Dyson J, Chai JG. Depletion of regulatory $\mathrm{T}$ cells by anti-GITR $\mathrm{mAb}$ as a novel mechanism for cancer immunotherapy. Cancer Immunol Immunother. (2010) 59:136777. doi: 10.1007/s00262-010-0866-5

55. Simpson TR, Li F, Montalvo-Ortiz W, Sepulveda MA, Bergerhoff K, Arce F, et al. Fc-dependent depletion of tumor-infiltrating regulatory $\mathrm{T}$ cells co-defines the efficacy of anti-CTLA-4 therapy against melanoma. J Exp Med. (2013) 210:1695-710. doi: 10.1084/jem.20130579

56. Selby MJ, Engelhardt JJ, Quigley M, Henning KA, Chen T, Srinivasan M, et al. Anti-CTLA-4 antibodies of IgG2a isotype enhance antitumor activity through reduction of intratumoral regulatory T cells. Cancer Immunol Res. (2013) 1:32-42. doi: 10.1158/2326-6066.CIR-13-0013

57. Bulliard Y, Jolicoeur R, Zhang J, Dranoff G, Wilson NS, Brogdon JL. OX40 engagement depletes intratumoral tregs via activating Fc $\gamma$ Rs, leading to antitumor efficacy. Immunol Cell Biol. (2014) 92:475-80. doi: 10.1038/icb.2014.26

58. Arce Vargas F, Furness AJS, Litchfield K, Joshi K, Rosenthal R, Ghorani E, et al. Fc effector function contributes to the activity of human anti-CTLA-4 antibodies. Cancer Cell. (2018) 33:649-63.e4. doi: 10.1016/j.ccell.2018.02.010
59. Ingram JR, Blomberg OS, Rashidian M, Ali L, Garforth S, Fedorov E, et al. Anti-CTLA-4 therapy requires an Fc domain for efficacy. Proc Natl Acad Sci USA. (2018) 115:3912-7. doi: 10.1073/pnas.1801524115

60. Sugiyama D, Nishikawa H, Maeda Y, Nishioka M, Tanemura A, Katayama I, et al. Anti-CCR4 mAb selectively depletes effector-type FoxP3+CD4+ regulatory T cells, evoking antitumor immune responses in humans. Proc Natl Acad Sci USA. (2013) 110:17945-50. doi: 10.1073/pnas.1316796110

61. Doi $\mathrm{T}$, Muro K, Ishii $\mathrm{H}$, Kato $\mathrm{T}$, Tsushima $\mathrm{T}$, Takenoyama $\mathrm{M}$, et al. A phase I study of the anti-CC chemokine receptor 4 antibody, mogamulizumab, in combination with nivolumab in patients with advanced or metastatic solid tumors. Clin Cancer Res. (2019) 25:661422. doi: 10.1158/1078-0432.CCR-19-1090

62. Kurtulus S, Sakuishi K, Ngiow SF, Joller N, Tan DJ, Teng MW, et al. TIGIT predominantly regulates the immune response via regulatory T cells. J Clin Invest. (2015) 125:4053-62. doi: 10.1172/JCI81187

63. Bournazos S, Wang TT, Dahan R, Maamary J, Ravetch JV. Signaling by antibodies: recent progress. Annu Rev Immunol. (2017) 35:285311. doi: 10.1146/annurev-immunol-051116-052433

64. Arce Vargas F, Furness AJS, Solomon I, Joshi K, Mekkaoui L, Lesko MH, et al. Fc-optimized anti-CD25 depletes tumor-infiltrating regulatory T cells and synergizes with PD-1 blockade to eradicate established tumors. Immunity. (2017) 46:577-86. doi: 10.1016/j.immuni.2017.03.013

65. Josefowicz SZ, Lu LF, Rudensky AY. Regulatory T cells: mechanisms of differentiation and function. Annu Rev Immunol. (2012) 30:53164. doi: 10.1146/annurev.immunol.25.022106.141623

66. van Gool F, Nguyen MLT, Mumbach MR, Satpathy AT, Rosenthal WL, Giacometti S, et al. A mutation in the transcription factor Foxp3 drives T helper 2 effector function in regulatory T cells. Immunity. (2019) 50:36277.e6. doi: 10.1016/j.immuni.2018.12.016

67. Francisco LM, Sage PT, Sharpe AH. The PD-1 pathway in tolerance and autoimmunity. Immunol Rev. (2010) 236:21942. doi: 10.1111/j.1600-065X.2010.00923.x

68. Wan YY, Flavell RA. Regulatory T-cell functions are subverted and converted owing to attenuated Foxp3 expression. Nature. (2007) 445:76670. doi: 10.1038/nature05479

69. Delgoffe GM, Woo SR, Turnis ME, Gravano DM, Guy C, Overacre AE, et al. Stability and function of regulatory $\mathrm{T}$ cells is maintained by a neuropilin1-semaphorin-4a axis. Nature. (2013) 501:252-6. doi: 10.1038/nature 12428

70. Overacre-Delgoffe AE, Chikina M, Dadey RE, Yano H, Brunazzi EA, Shayan $\mathrm{G}$, et al. Interferon-gamma drives Treg fragility to promote anti-tumor immunity. Cell. (2017) 169:1130-41.e11. doi: 10.1016/j.cell.2017.05.005

71. DuPage M, Chopra G, Quiros J, Rosenthal WL, Morar MM, Holohan D, et al. The chromatin-modifying enzyme Ezh2 is critical for the maintenance of regulatory T cell identity after activation. Immunity. (2015) 42:22738. doi: 10.1016/j.immuni.2015.01.007

72. Wang D, Quiros J, Mahuron K, Pai CC, Ranzani V, Young A, et al. Targeting EZH2 reprograms intratumoral regulatory $\mathrm{T}$ cells to enhance cancer immunity. Cell Rep. (2018) 23:3262-74. doi: 10.1016/j.celrep.2018.05.050

73. Goswami S, Apostolou I, Zhang J, Skepner J, Anandhan S, Zhang X, et al. Modulation of EZH2 expression in T cells improves efficacy of anti-CTLA-4 therapy. J Clin Invest. (2018) 128:3813-8. doi: 10.1172/JCI99760

74. Godfrey DI, Le Nours J, Andrews DM, Uldrich AP, Rossjohn J. Unconventional T cell targets for cancer immunotherapy. Immunity. (2018) 48:453-73. doi: 10.1016/j.immuni.2018.03.009

75. Kawano T, Cui J, Koezuka Y, Toura I, Kaneko Y, Motoki $\mathrm{K}$, et al. CD1d-restricted and TCR-mediated activation of valpha14 NKT cells by glycosylceramides. Science. (1997) 278:1626-9. doi: 10.1126/science.278.5343.1626

76. Metelitsa LS, Naidenko OV, Kant A, Wu HW, Loza MJ, Perussia $B$, et al. Human NKT cells mediate antitumor cytotoxicity directly by recognizing target cell CD1d with bound ligand or indirectly by producing IL-2 to activate NK cells. J Immunol. (2001) 167:311422. doi: 10.4049/jimmunol.167.6.3114

77. Coquet JM, Chakravarti S, Kyparissoudis K, McNab FW, Pitt LA, McKenzie BS, et al. Diverse cytokine production by NKT cell subsets and identification of an IL-17-producing CD4-NK1.1- NKT cell population. Proc Natl Acad Sci USA. (2008) 105:11287-92. doi: 10.1073/pnas.0801631105 
78. McEwen-Smith RM, Salio M, Cerundolo V. The regulatory role of invariant NKT cells in tumor immunity. Cancer Immunol Res. (2015) 3:42535. doi: 10.1158/2326-6066.CIR-15-0062

79. Hermans IF, Silk JD, Gileadi U, Salio M, Mathew B, Ritter G, et al. NKT cells enhance $\mathrm{CD} 4+$ and $\mathrm{CD} 8+\mathrm{T}$ cell responses to soluble antigen in vivo through direct interaction with dendritic cells. J Immunol. (2003) 171:51407. doi: 10.4049/jimmunol.171.10.5140

80. Fujii S, Shimizu K, Smith C, Bonifaz L, Steinman RM. Activation of natural killer $\mathrm{T}$ cells by alpha-galactosylceramide rapidly induces the full maturation of dendritic cells in vivo and thereby acts as an adjuvant for combined CD4 and CD8 T cell immunity to a coadministered protein. J Exp Med. (2003) 198:267-79. doi: 10.1084/jem.20030324

81. Silk JD, Hermans IF, Gileadi U, Chong TW, Shepherd D, Salio M, et al. Utilizing the adjuvant properties of CD1d-dependent NK T cells in $\mathrm{T}$ cell-mediated immunotherapy. J Clin Invest. (2004) 114:180011. doi: 10.1172/JCI200422046

82. Song L, Asgharzadeh S, Salo J, Engell K, Wu HW, Sposto R, et al. Valpha24-invariant NKT cells mediate antitumor activity via killing of tumor-associated macrophages. J Clin Invest. (2009) 119:1524-36. doi: 10.1172/JCI37869

83. Bae EA, Seo H, Kim BS, Choi J, Jeon I, Shin KS, et al. Activation of NKT cells in an anti-PD-1-resistant tumor model enhances antitumor immunity by reinvigorating exhausted CD8 T cells. Cancer Res. (2018) 78:5315-26. doi: 10.1158/0008-5472.CAN-18-0734

84. Ishii K, Shimizu M, Kogo H, Negishi Y, Tamura H, Morita R, et al. A combination of check-point blockade and alpha-galactosylceramide elicits long-lasting suppressive effects on murine hepatoma cell growth in vivo. Immunobiology. (2020) 225:151860. doi: 10.1016/j.imbio.2019.10.009

85. O’Konek JJ, Illarionov P, Khursigara DS, Ambrosino E, Izhak L, Castillo $\mathrm{BF}$, et al. Mouse and human iNKT cell agonist $\beta$-mannosylceramide reveals a distinct mechanism of tumor immunity. J Clin Invest. (2011) 121:68394. doi: 10.1172/JCI42314

86. Awad W, Le Nours J, Kjer-Nielsen L, McCluskey J, Rossjohn J. Mucosalassociated invariant $\mathrm{T}$ cell receptor recognition of small molecules presented by MR1. Immunol Cell Biol. (2018) 96:588-97. doi: 10.1111/imcb.12017

87. Corbett AJ, Eckle SB, Birkinshaw RW, Liu L, Patel O, Mahony J, et al. Tcell activation by transitory neo-antigens derived from distinct microbial pathways. Nature. (2014) 509:361-5. doi: 10.1038/nature13160

88. Kjer-Nielsen L, Patel O, Corbett AJ, Le Nours J, Meehan B, Liu L, et al. MR1 presents microbial vitamin B metabolites to MAIT cells. Nature. (2012) 491:717-23. doi: 10.1038/nature11605

89. Mascanfroni ID, Yeste A, Vieira SM, Burns EJ, Patel B, Sloma I, et al. IL-27 acts on DCs to suppress the T cell response and autoimmunity by inducing expression of the immunoregulatory molecule CD39. Nat Immunol. (2013) 14:1054-63. doi: 10.1038/ni.2695

90. Treiner E, Duban L, Bahram S, Radosavljevic M, Wanner V, Tilloy F, et al. Selection of evolutionarily conserved mucosal-associated invariant $\mathrm{T}$ cells by MR1. Nature. (2003) 422:164-9. doi: 10.1038/nature01433

91. Loh L, Wang Z, Sant S, Koutsakos M, Jegaskanda S, Corbett AJ, et al. Human mucosal-associated invariant $T$ cells contribute to antiviral influenza immunity via IL-18-dependent activation. Proc Natl Acad Sci USA. (2016) 113:10133-8. doi: 10.1073/pnas.1610750113

92. van Wilgenburg B, Scherwitzl I, Hutchinson EC, Leng T, Kurioka A, Kulicke C, et al. MAIT cells are activated during human viral infections. Nat Commun. (2016) 7:11653. doi: 10.1038/ncomms11653

93. Gherardin NA, Souter MN, Koay HF, Mangas KM, Seemann T, Stinear TP, et al. Human blood MAIT cell subsets defined using MR1 tetramers. Immunol Cell Biol. (2018) 96:507-25. doi: 10.1111/imcb.12021

94. Le Bourhis L, Dusseaux M, Bohineust A, Bessoles S, Martin E, Premel V, et al. MAIT cells detect and efficiently lyse bacterially-infected epithelial cells. PLoS Pathog. (2013) 9:e1003681. doi: 10.1371/journal.ppat.1003681

95. Kurioka A, Ussher JE, Cosgrove C, Clough C, Fergusson JR, Smith $\mathrm{K}$, et al. MAIT cells are licensed through granzyme exchange to kill bacterially sensitized targets. Mucosal Immunol. (2015) 8:42940. doi: $10.1038 / \mathrm{mi} .2014 .81$

96. Won EJ, Ju JK, Cho YN, Jin HM, Park KJ, Kim TJ, et al. Clinical relevance of circulating mucosal-associated invariant $\mathrm{T}$ cell levels and their anti-cancer activity in patients with mucosal-associated cancer. Oncotarget. (2016) 7:76274-90. doi: 10.18632/oncotarget.11187

97. Sundstrom P, Ahlmanner F, Akeus P, Sundquist M, Alsen S, Yrlid U, et al. Human mucosa-associated invariant $\mathrm{T}$ cells accumulate in colon adenocarcinomas but produce reduced amounts of IFN-gamma. J Immunol. (2015) 195:3472-81. doi: 10.4049/jimmunol.1500258

98. Zabijak L, Attencourt C, Guignant C, Chatelain D, Marcelo P, Marolleau JP, et al. Increased tumor infiltration by mucosal-associated invariant $\mathrm{T}$ cells correlates with poor survival in colorectal cancer patients. Cancer Immunol Immunother. (2015) 64:1601-8. doi: 10.1007/s00262-015-1764-7

99. Ling L, Lin Y, Zheng W, Hong S, Tang X, Zhao P, et al. Circulating and tumorinfiltrating mucosal associated invariant T (MAIT) cells in colorectal cancer patients. Sci Rep. (2016) 6:20358. doi: 10.1038/srep20358

100. Melo AM, O’Brien AM, Phelan JJ, Kennedy SA, Wood NAW, Veerapen N, et al. Mucosal-associated invariant $\mathrm{T}$ cells display diminished effector capacity in oesophageal adenocarcinoma. Front Immunol. (2019) 10:1580. doi: 10.3389/fimmu.2019.01580

101. Godfrey DI, Koay HF, McCluskey J, Gherardin NA. The biology and functional importance of MAIT cells. Nat Immunol. (2019) 20:111028. doi: 10.1038/s41590-019-0444-8

102. Yan J, Allen S, McDonald E, Das I, Mak JYW, Liu L, et al. MAIT cells promote tumor initiation, growth, and metastases via tumor MR1. Cancer Discov. (2020) 10:124-41. doi: 10.1158/2159-8290.CD-19-0569

103. Gopalakrishnan V, Spencer CN, Nezi L, Reuben A, Andrews MC, Karpinets TV, et al. Gut microbiome modulates response to antiPD-1 immunotherapy in melanoma patients. Science. (2018) 359:97103. doi: $10.1126 /$ science.aan 4236

104. Vetizou M, Pitt JM, Daillere R, Lepage P, Waldschmitt N, Flament $\mathrm{C}$, et al. Anticancer immunotherapy by CTLA-4 blockade relies on the gut microbiota. Science. (2015) 350:1079-84. doi: 10.1126/science.aa d1329

105. Sivan A, Corrales L, Hubert N, Williams JB, Aquino-Michaels K, Earley ZM, et al. Commensal Bifidobacterium promotes antitumor immunity and facilitates anti-PD-L1 efficacy. Science. (2015) 350:10849. doi: 10.1126/science.aac4255

106. Pang Y, Gara SK, Achyut BR, Li Z, Yan HH, Day CP, et al. TGF- $\beta$ signaling in myeloid cells is required for tumor metastasis. Cancer Discov. (2013) 3:936-51. doi: 10.1158/2159-8290.CD-12-0527

107. Novitskiy SV, Pickup MW, Chytil A, Polosukhina D, Owens P, Moses HL. Deletion of TGF- $\beta$ signaling in myeloid cells enhances their antitumorigenic properties. J Leukoc Biol. (2012) 92:641-51. doi: 10.1189/jlb.12 11639

108. Gao Y, Souza-Fonseca-Guimaraes F, Bald T, Ng SS, Young A, Ngiow SF, et al. Tumor immunoevasion by the conversion of effector NK cells into type 1 innate lymphoid cells. Nat Immunol. (2017) 18:100415. doi: 10.1038/ni.3800

109. Thomas DA, Massague J. TGF- $\beta$ directly targets cytotoxic T cell functions during tumor evasion of immune surveillance. Cancer Cell. (2005) 8:36980. doi: 10.1016/j.ccr.2005.10.012

110. Chen ML, Pittet MJ, Gorelik L, Flavell RA, Weissleder R, von Boehmer $\mathrm{H}$, et al. Regulatory $\mathrm{T}$ cells suppress tumor-specific CD8 $\mathrm{T}$ cell cytotoxicity through TGF- $\beta$ signals in vivo. Proc Natl Acad Sci USA. (2005) 102:41924. doi: 10.1073/pnas.0408197102

111. Budhu S, Schaer DA, Li Y, Toledo-Crow R, Panageas K, Yang X, et al. Blockade of surface-bound TGF- $\beta$ on regulatory $\mathrm{T}$ cells abrogates suppression of effector T cell function in the tumor microenvironment. Sci Signal. (2017) 10:eaak9702. doi: 10.1126/scisignal.aak9702

112. Park BV, Freeman ZT, Ghasemzadeh A, Chattergoon MA, Rutebemberwa A, Steigner J, et al. TGF $\beta 1$-mediated SMAD3 enhances PD-1 expression on antigen-specific T cells in cancer. Cancer Discov. (2016) 6:136681. doi: 10.1158/2159-8290.CD-15-1347

113. Mariathasan S, Turley SJ, Nickles D, Castiglioni A, Yuen K, Wang Y, et al. TGF $\beta$ attenuates tumour response to PD-L1 blockade by contributing to exclusion of T cells. Nature. (2018) 554:544-8. doi: 10.1038/nature25501

114. Sow HS, Ren J, Camps M, Ossendorp F, Ten Dijke P. Combined inhibition of TGF- $\beta$ signaling and the PD-L1 immune checkpoint is differentially effective in tumor models. Cells. (2019) 8:320. doi: 10.3390/cells 8040320 
115. Principe DR, Park A, Dorman MJ, Kumar S, Viswakarma N, Rubin J, et al. TGF $\beta$ blockade augments PD-1 inhibition to promote T-cellmediated regression of pancreatic cancer. Mol Cancer Ther. (2019) 18:61320. doi: 10.1158/1535-7163.MCT-18-0850

116. Ravi R, Noonan KA, Pham V, Bedi R, Zhavoronkov A, Ozerov IV, et al. Bifunctional immune checkpoint-targeted antibody-ligand traps that simultaneously disable TGF $\beta$ enhance the efficacy of cancer immunotherapy. Nat Commun. (2018) 9:741. doi: 10.1038/s41467-017-02696-6

117. Dodagatta-Marri E, Meyer DS, Reeves MQ, Paniagua R, To MD, Binnewies $\mathrm{M}$, et al. $\alpha$-PD-1 therapy elevates Treg/Th balance and increases tumor cell pSmad 3 that are both targeted by alpha-TGF $\beta$ antibody to promote durable rejection and immunity in squamous cell carcinomas. J Immunother Cancer. (2019) 7:62. doi: 10.1186/s40425-018-0493-9

118. Holmgaard RB, Schaer DA, Li Y, Castaneda SP, Murphy MY, Xu X, et al. Targeting the TGF $\beta$ pathway with galunisertib, a TGF $\beta$ RI small molecule inhibitor, promotes anti-tumor immunity leading to durable, complete responses, as monotherapy and in combination with checkpoint blockade. J Immunother Cancer. (2018) 6:47. doi: 10.1186/s40425-018-0356-4

119. Herbertz S, Sawyer JS, Stauber AJ, Gueorguieva I, Driscoll KE, Estrem ST, et al. Clinical development of galunisertib (LY2157299 monohydrate), a small molecule inhibitor of transforming growth factor- $\beta$ signaling pathway. Drug Des Devel Ther. (2015) 9:4479-99. doi: 10.2147/DDDT.S86621

120. Martin CJ, Datta A, Littlefield C, Kalra A, Chapron C, Wawersik S, et al. Selective inhibition of TGF $\beta 1$ activation overcomes primary resistance to checkpoint blockade therapy by altering tumor immune landscape. Sci Transl Med. (2020) 12:eaay8456. doi: 10.1126/scitranslmed.aay8456

121. Voron T, Colussi O, Marcheteau E, Pernot S, Nizard M, Pointet AL, et al. VEGF-A modulates expression of inhibitory checkpoints on CD8 + T cells in tumors. J Exp Med. (2015) 212:139-48. doi: 10.1084/jem.20140559

122. Kim CG, Jang $M$, Kim Y, Leem G, Kim KH, Lee $H$, et al. VEGF-A drives TOX-dependent $\mathrm{T}$ cell exhaustion in anti-PD-1resistant microsatellite stable colorectal cancers. Sci Immunol. (2019) 4:eaay0555. doi: 10.1126/sciimmunol.aay0555

123. Dudley JC, Lin MT, Le DT, Eshleman JR. Microsatellite instability as a biomarker for PD-1 blockade. Clin Cancer Res. (2016) 22:81320. doi: 10.1158/1078-0432.CCR-15-1678

124. Le DT, Uram JN, Wang H, Bartlett BR, Kemberling H, Eyring AD, et al. PD1 blockade in tumors with mismatch-repair deficiency. N Engl J Med. (2015) 372:2509-20. doi: 10.1056/NEJMoa1500596

125. Courau T, Nehar-Belaid D, Florez L, Levacher B, Vazquez T, Brimaud F, et al. TGF- $\beta$ and VEGF cooperatively control the immunotolerant tumor environment and the efficacy of cancer immunotherapies. JCI Insight. (2016) 1:e85974. doi: 10.1172/jci.insight.85974

126. Young A, Mittal D, Stagg J, Smyth MJ. Targeting cancer-derived adenosine: new therapeutic approaches. Cancer Discov. (2014) 4:87988. doi: 10.1158/2159-8290.CD-14-0341

127. Loi S, Pommey S, Haibe-Kains B, Beavis PA, Darcy PK, Smyth MJ, et al. CD73 promotes anthracycline resistance and poor prognosis in triple negative breast cancer. Proc Natl Acad Sci USA. (2013) 110:110916. doi: 10.1073/pnas.1222251110

128. Nagate Y, Ezoe S, Fujita J, Okuzakis D, Motooka D, Ishibashi T, et al. Ectonucleotidase CD39 is highly expressed on ATLL cells and is responsible for their immunosuppressive function. Leukemia. (2020). doi: 10.1038/s41375-020-0788-y. [Epub ahead of print].

129. Bastid J, Regairaz A, Bonnefoy N, Dejou C, Giustiniani J, Laheurte C, et al. Inhibition of CD39 enzymatic function at the surface of tumor cells alleviates their immunosuppressive activity. Cancer Immunol Res. (2015) 3:254-65. doi: 10.1158/2326-6066.CIR-14-0018

130. Cai XY, Wang XF, Li J, Dong JN, Liu JQ, Li NP, et al. High expression of CD39 in gastric cancer reduces patient outcome following radical resection. Oncol Lett. (2016) 12:4080-6. doi: 10.3892/ol.2016.5189

131. Chen S, Fan J, Zhang M, Qin L, Dominguez D, Long A, et al. CD73 expression on effector $\mathrm{T}$ cells sustained by TGF- $\beta$ facilitates tumor resistance to anti-4-1BB/CD137 therapy. Nat Commun. (2019) 10:150. doi: 10.1038/s41467-018-08123-8

132. Ryzhov SV, Pickup MW, Chytil A, Gorska AE, Zhang Q, Owens P, et al. Role of TGF- $\beta$ signaling in generation of CD39+CD73+ myeloid cells in tumors. J Immunol. (2014) 193:3155-64. doi: 10.4049/jimmunol.1400578
133. Young A, Ngiow SF, Barkauskas DS, Sult E, Hay C, Blake SJ, et al. Co-inhibition of CD73 and A2AR adenosine signaling improves anti-tumor immune responses. Cancer Cell. (2016) 30:391-403. doi: 10.1016/j.ccell.2016.06.025

134. Young A, Ngiow SF, Gao Y, Patch AM, Barkauskas DS, Messaoudene $\mathrm{M}$, et al. A2AR adenosine signaling suppresses natural killer cell maturation in the tumor microenvironment. Cancer Res. (2018) 78:100316. doi: 10.1158/0008-5472.CAN-17-2826

135. Reinhardt J, Landsberg J, Schmid-Burgk JL, Ramis BB, Bald T, Glodde $\mathrm{N}$, et al. MAPK signaling and inflammation link melanoma phenotype switching to induction of CD73 during immunotherapy. Cancer Res. (2017) 77:4697-709. doi: 10.1158/0008-5472.CAN-17-0395

136. Blay J, White TD, Hoskin DW. The extracellular fluid of solid carcinomas contains immunosuppressive concentrations of adenosine. Cancer Res. (1997) 57:2602-5.

137. Hatfield SM, Kjaergaard J, Lukashev D, Belikoff B, Schreiber $\mathrm{TH}$, Sethumadhavan S, et al. Systemic oxygenation weakens the hypoxia and hypoxia inducible factor lalpha-dependent and extracellular adenosine-mediated tumor protection. J Mol Med. (2014) 92:1283-92. doi: 10.1007/s00109-014-1189-3

138. Iannone R, Miele L, Maiolino P, Pinto A, Morello S. Adenosine limits the therapeutic effectiveness of anti-CTLA4 mAb in a mouse melanoma model. Am J Cancer Res. (2014) 4:172-81.

139. Mittal D, Young A, Stannard K, Yong M, Teng MW, Allard B, et al. Antimetastatic effects of blocking PD-1 and the adenosine A2A receptor. Cancer Res. (2014) 74:3652-8. doi: 10.1158/0008-5472.CAN-14-0957

140. Beavis PA, Henderson MA, Giuffrida L, Mills JK, Sek K, Cross RS, et al. Targeting the adenosine $2 \mathrm{~A}$ receptor enhances chimeric antigen receptor T cell efficacy. J Clin Invest. (2017) 127:929-41. doi: 10.1172/JCI 89455

141. Young A, Ngiow SF, Madore J, Reinhardt J, Landsberg J, Chitsazan A, et al. Targeting adenosine in BRAF-mutant melanoma reduces tumor growth and metastasis. Cancer Res. (2017) 77:4684-96. doi: 10.1158/0008-5472.CAN-17-0393

142. Chen L, Diao L, Yang Y, Yi X, Rodriguez BL, Li Y, et al. CD38-mediated immunosuppression as a mechanism of tumor cell escape from PD-1/PD-L1 blockade. Cancer Discov. (2018) 8:1156-75. doi: 10.1158/2159-8290.CD-17-1033

143. Hatfield SM, Kjaergaard J, Lukashev D, Schreiber TH, Belikoff $\mathrm{B}$, Abbott R, et al. Immunological mechanisms of the antitumor effects of supplemental oxygenation. Sci Transl Med. (2015) 7:277ra30. doi: 10.1126/scitranslmed.aaa1260

144. Li XY, Moesta AK, Xiao C, Nakamura K, Casey M, Zhang H, et al. Targeting CD39 in cancer reveals an extracellular ATP- and inflammasome-driven tumor immunity. Cancer Discov. (2019) 9:175473. doi: 10.1158/2159-8290.CD-19-0541

145. Ma Y, Adjemian S, Mattarollo SR, Yamazaki T, Aymeric L, Yang $H$, et al. Anticancer chemotherapy-induced intratumoral recruitment and differentiation of antigen-presenting cells. Immunity. (2013) 38:72941. doi: 10.1016/j.immuni.2013.03.003

146. Perrot I, Michaud HA, Giraudon-Paoli M, Augier S, Docquier A, Gros L, et al. Blocking antibodies targeting the CD39/CD73 immunosuppressive pathway unleash immune responses in combination cancer therapies. Cell Rep. (2019) 27:2411-25.e9. doi: 10.1016/j.celrep.2019.04.091

147. Fong L, Hotson A, Powderly JD, Sznol M, Heist RS, Choueiri TK, et al. Adenosine $2 \mathrm{~A}$ receptor blockade as an immunotherapy for treatment-refractory renal cell cancer. Cancer Discov. (2020) 10:4053. doi: 10.1158/2159-8290.CD-19-0980

148. Zelenay S, van der Veen AG, Bottcher JP, Snelgrove KJ, Rogers N, Acton $\mathrm{SE}$, et al. Cyclooxygenase-dependent tumor growth through evasion of immunity. Cell. (2015) 162:1257-70. doi: 10.1016/j.cell.2015.08.015

149. Hamada T, Cao Y, Qian ZR, Masugi Y, Nowak JA, Yang J, et al. Aspirin use and colorectal cancer survival according to tumor CD274 (Programmed cell death 1 ligand 1) Expression Status. J Clin Oncol. (2017) 35:183644. doi: 10.1200/JCO.2016.70.7547

150. Markosyan N, Li J, Sun YH, Richman LP, Lin JH, Yan F, et al. Tumor cell-intrinsic EPHA2 suppresses anti-tumor immunity by regulating PTGS2 (COX-2). J Clin Invest. (2019) 130:3594-609. doi: 10.1172/JCI127755 
151. Chalabi M, Fanchi LF, Dijkstra KK, Van den Berg JG, Aalbers AG, Sikorska K, et al. Neoadjuvant immunotherapy leads to pathological responses in MMRproficient and MMR-deficient early-stage colon cancers. Nat Med. (2020) 26:566-76. doi: 10.1038/s41591-020-0805-8

152. Prendergast GC, Smith C, Thomas S, Mandik-Nayak L, Laury-Kleintop $\mathrm{L}$, Metz R, et al. Indoleamine 2,3-dioxygenase pathways of pathogenic inflammation and immune escape in cancer. Cancer Immunol Immunother. (2014) 63:721-35. doi: 10.1007/s00262-014-1549-4

153. Spranger S, Koblish HK, Horton B, Scherle PA, Newton R, Gajewski TF. Mechanism of tumor rejection with doublets of CTLA-4, PD-1/PD-L1, or IDO blockade involves restored IL-2 production and proliferation of CD8(+) T cells directly within the tumor microenvironment. J Immunother Cancer. (2014) 2:3. doi: 10.1186/2051-1426-2-3

154. Holmgaard RB, Zamarin D, Munn DH, Wolchok JD, Allison JP. Indoleamine 2,3-dioxygenase is a critical resistance mechanism in antitumor T cell immunotherapy targeting CTLA-4. J Exp Med. (2013) 210:1389402. doi: 10.1084/jem.20130066

155. Long GV, Dummer R, Hamid O, Gajewski TF, Caglevic C, Dalle S, et al. Epacadostat plus pembrolizumab versus placebo plus pembrolizumab in patients with unresectable or metastatic melanoma (ECHO-301/KEYNOTE252): a phase 3, randomised, double-blind study. Lancet Oncol. (2019) 20:1083-97. doi: 10.1016/S1470-2045(19)30274-8

156. Messenheimer DJ, Jensen SM, Afentoulis ME, Wegmann KW, Feng Z, Friedman DJ, et al. Timing of PD-1 blockade is critical to effective combination immunotherapy with anti-OX40. Clin Cancer Res. (2017) 23:6165-77. doi: 10.1158/1078-0432.CCR-16-2677

157. Shrimali RK, Ahmad S, Verma V, Zeng P, Ananth S, Gaur P, et al. Concurrent PD-1 blockade negates the effects of OX40 agonist antibody in combination immunotherapy through inducing T-cell apoptosis. Cancer Immunol Res. (2017) 5:755-66. doi: 10.1158/2326-6066.CIR-17-0292

158. Dong MB, Wang G, Chow RD, Ye L, Zhu L, Dai X, et al. Systematic immunotherapy target discovery using genome-scale in vivo CRISPR screens in CD8 T cells. Cell. (2019) 178:1189-204.e23. doi: 10.1016/j.cell.2019.07.044

159. Lizotte PH, Hong RL, Luster TA, Cavanaugh ME, Taus LJ, Wang $S$, et al. A high-throughput immune-oncology screen identifies EGFR inhibitors as potent enhancers of antigen-specific cytotoxic t-lymphocyte tumor cell killing. Cancer Immunol Res. (2018) 6:1511-23. doi: 10.1158/1538-7445.AM2018-4935

160. Khandelwal N, Breinig M, Speck T, Michels T, Kreutzer C, Sorrentino A, et al. A high-throughput RNAi screen for detection of immune-checkpoint molecules that mediate tumor resistance to cytotoxic T lymphocytes. EMBO Mol Med. (2015) 7:450-63. doi: 10.15252/emmm.201404414

161. Kather JN, Charoentong P, Suarez-Carmona M, Herpel E, Klupp F, Ulrich A, et al. High-throughput screening of combinatorial immunotherapies with patient-specific in silico models of metastatic colorectal cancer. Cancer Res. (2018) 78:5155-63. doi: 10.1158/0008-5472.CAN-18-1126

162. Sharma P, Hu-Lieskovan S, Wargo JA, Ribas A. Primary, adaptive, and acquired resistance to cancer immunotherapy. Cell. (2017) 168:70723. doi: $10.1016 /$ j.cell.2017.01.017

163. Kluger HM, Tawbi HA, Ascierto ML, Bowden M, Callahan MK, Cha E, et al. Defining tumor resistance to PD-1 pathway blockade: recommendations from the first meeting of the SITC immunotherapy resistance taskforce. $J$ Immunother Cancer. (2020) 8:e000398. doi: 10.1136/jitc-2019-000398

164. Loo K, Tsai KK, Mahuron K, Liu J, Pauli ML, Sandoval PM, et al. Partially exhausted tumor-infiltrating lymphocytes predict response to combination immunotherapy. JCI Insight. (2017) 2:e93433. doi: 10.1172/jci.insight.93433

165. Bilen MA, Shabto JM, Martini DJ, Liu Y, Lewis C, Collins H, et al. Sites of metastasis and association with clinical outcome in advanced stage cancer patients treated with immunotherapy. BMC Cancer. (2019) 19:857. doi: 10.1186/s12885-019-6073-7

166. Daud AI, Loo K, Pauli ML, Sanchez-Rodriguez R, Sandoval PM, Taravati K, et al. Tumor immune profiling predicts response to anti-PD-1 therapy in human melanoma. J Clin Invest. (2016) 126:3447-52. doi: 10.1172/JCI87324

167. Larkin J, Chiarion-Sileni V, Gonzalez R, Grob JJ, Cowey CL, Lao CD, et al. Combined nivolumab and ipilimumab or monotherapy in untreated melanoma. N Engl J Med. (2015) 373:23-34. doi: 10.1056/NEJMoa1504030
168. Hu-Lieskovan S, Mok S, Homet Moreno B, Tsoi J, Robert L, Goedert L, et al. Improved antitumor activity of immunotherapy with BRAF and MEK inhibitors in BRAF(V600E) melanoma. Sci Transl Med. (2015) 7:279ra41. doi: 10.1126/scitranslmed.aaa4691

169. Ribas A, Hodi FS, Callahan M, Konto C, Wolchok J. Hepatotoxicity with combination of vemurafenib and ipilimumab. N Engl J Med. (2013) 368:1365-6. doi: 10.1056/NEJMc1302338

170. Minor DR, Puzanov I, Callahan MK, Hug BA, Hoos A. Severe gastrointestinal toxicity with administration of trametinib in combination with dabrafenib and ipilimumab. Pigment Cell Melanoma Res. (2015) 28:611-2. doi: $10.1111 / \mathrm{pcmr} .12383$

171. Young A, Quandt Z, Bluestone JA. The balancing act between cancer immunity and autoimmunity in response to immunotherapy. Cancer Immunol Res. (2018) 6:1445-52. doi: 10.1158/2326-6066.CIR-18-0487

172. Du X, Liu M, Su J, Zhang P, Tang F, Ye P, et al. Uncoupling therapeutic from immunotherapy-related adverse effects for safer and effective antiCTLA-4 antibodies in CTLA4 humanized mice. Cell Res. (2018) 28:43347. doi: 10.1038/s41422-018-0012-Z

173. Menzies AM, Johnson DB, Ramanujam S, Atkinson VG, Wong ANM, Park JJ, et al. Anti-PD-1 therapy in patients with advanced melanoma and preexisting autoimmune disorders or major toxicity with ipilimumab. Ann Oncol. (2017) 28:368-76. doi: 10.1093/annonc/mdw443

174. Shah NJ, Al-Shbool G, Blackburn M, Cook M, Belouali A, Liu SV, et al. Safety and efficacy of immune checkpoint inhibitors (ICIs) in cancer patients with HIV, hepatitis B, or hepatitis C viral infection. J Immunother Cancer. (2019) 7:353. doi: 10.1186/s40425-019-0771-1

175. Herbaux C, Gauthier J, Brice P, Drumez E, Ysebaert L, Doyen $\mathrm{H}$, et al. Efficacy and tolerability of nivolumab after allogeneic transplantation for relapsed Hodgkin lymphoma. Blood. (2017) 129:2471-8. doi: 10.1182/blood-2016-11-749556

176. Pai CS, Simons DM, Lu X, Evans M, Wei J, Wang YH, et al. Tumor-conditional anti-CTLA4 uncouples antitumor efficacy from immunotherapy-related toxicity. J Clin Invest. (2019) 129:349-63. doi: 10.1172/JCI123391

177. Wu L, Seung E, Xu L, Rao E, Lord DM, Wei RR, et al. Trispecific antibodies enhance the therapeutic efficacy of tumor-directed $\mathrm{T}$ cells through T cell receptor co-stimulation. Nature Cancer. (2020) 1:8698. doi: 10.1038/s43018-019-0004-z

178. Kvarnhammar AM, Veitonmaki N, Hagerbrand K, Dahlman A, Smith KE, Fritzell S, et al. The CTLA-4 x OX40 bispecific antibody ATOR-1015 induces anti-tumor effects through tumor-directed immune activation. $J$ Immunother Cancer. (2019) 7:103. doi: 10.1186/s40425-019-0570-8

179. Wang H, Mooney DJ. Biomaterial-assisted targeted modulation of immune cells in cancer treatment. Nat Mater. (2018) 17:761-72. doi: 10.1038/s41563-018-0147-9

180. Johnston RJ, Su LJ, Pinckney J, Critton D, Boyer E, Krishnakumar A, et al. VISTA is an acidic pH-selective ligand for PSGL-1. Nature. (2019) 574:565-70. doi: 10.1038/s41586-019-1674-5

181. Wang M, Wang J, Wang R, Jiao S, Wang S, Zhang J, et al. Identification of a monoclonal antibody that targets PD-1 in a manner requiring PD-1 Asn58 glycosylation. Commun Biol. (2019) 2:392. doi: 10.1038/s42003-0190642-9

182. Sun L, Li CW, Chung EM, Yang R, Kim YS, Park AH, et al. Targeting glycosylated PD-1 induces potent anti-tumor immunity. Cancer Res. (2020) 80:2298-310. doi: 10.1158/0008-5472.CAN-19-3133

Conflict of Interest: The authors declare that the research was conducted in the absence of any commercial or financial relationships that could be construed as a potential conflict of interest.

Copyright $\odot 2020$ Ngiow and Young. This is an open-access article distributed under the terms of the Creative Commons Attribution License (CC BY). The use, distribution or reproduction in other forums is permitted, provided the original author(s) and the copyright owner(s) are credited and that the original publication in this journal is cited, in accordance with accepted academic practice. No use, distribution or reproduction is permitted which does not comply with these terms. 